\title{
Comparative petrography and organic geochemistry of different types of organic matter occurring in the Outer Carpathians rocks
}

\author{
Magdalena ZIELIŃSKA ${ }^{1, *}$, Monika FABIAŃSKA ${ }^{1}$, Dariusz WIĘCŁAW ${ }^{2}$ and Magdalena MISZ-KENNAN ${ }^{1}$ \\ 1 University of Silesia, Faculty of Natural Sciences, Institute of Earth Sciences, Będzińska 60, 41-200 Sosnowiec, Poland \\ 2 AGH University of Science and Technology, Faculty of Geology, Geophysics and Environmental Protection, \\ al. A. Mickiewicza 30, 30-059 Kraków, Poland
}

Zielińska, M., Fabiańska, M., Więcław, D., Misz-Kennan, M., 2020. Comparative petrography and organic geochemistry of different types of organic matter occurring in the Outer Carpathians rocks. Geological Quarterly, 64 (1): 165-184, doi: 10.7306/gq.1523

The characterization of organic matter (OM) in sedimentary rocks is important in many types of biological, geological and environmental research. The integrated use of microscopy and geochemistry, as here, is particularly useful in any attempt to define the origin and evolution of OM in sedimentary basins. The organic petrography and geochemistry different types of allogenic and authigenic OM from the Polish Outer Carpathian (POC) rocks were studied in present study to compare their genetic type, thermal maturity, depositional environment and post-sedimentation processes. Special attention was paid to redeposited coal clasts occurrences. The used techniques show differences in organic matter type originating from various sources. The organic petrography analysis shows that redeposited coal clasts (CC) and terrigenous organic matter (TOM) are composed predominantly of woody material (the gas-prone Type-III kerogen). Similar results were obtained during the Rock-Eval pyrolysis. Moreover, the GC-MS analysis of extracts indicated the additional source of OM, namely planktonic organic matter (POM) with oil-prone kerogen Type-I or II. This OM is in some cases high thermally mature and could potentially has allochthonous origin. The $n$-alkane, saturated and aromatic biomarker data revealed deposition of this POM in anoxic deltaic or close-shore sedimentary environments whereas the redeposited coal clasts were probably originally deposited in coal swamps as were the Upper Silesian bituminous coals.

Key words: Polish Outer Carpathians, redeposited organic matter, organic matter petrography, thermal maturity, biomarkers, Rock-Eval.

\section{INTRODUCTION}

Production, accumulation, deposition and preservation processes are essential for the existence of OM in source rocks. The type of OM incorporated into sediments depends mostly on the natural association of the various groups of organic materials in different facies provinces (Tissot and Welte,1984; Jiang et al., 2017). This matter can be supplied either in the form of dead or living particulate organic debris or as dissolved $\mathrm{OM}$. The $\mathrm{OM}$ may be autochthonous to where it is deposited, i.e., it may originate in the water column above or within the sediment hosting it or it may be allochthonous i.e., terrestrial higher plants contributing biomass to fluvial system that carry OM to the depositional environment (Galloway and Hobday, 1983; Arndt et al., 2013). The another source of $\mathrm{OM}$ is reworked or recycled material from preexisting sedimentary organic matter derived during the erosion and deposition of older sedimentary rocks. Of these three types of OM, the autochthonous and allochthonous contribu-

\footnotetext{
*Corresponding author, e-mail: magdalena.zielinska@us.edu.pl
}

Received: August 19, 2019; accepted: January 7, 2020; first published online: March 31, 2020 tions are important in the development of source rocks. The reworked OM is mostly degraded to the point where it has little or no capacity for being converted into oil and gas (Calvert and Pedersen, 1993) but can provide valuable information on supply sources for ancient and present-day sedimentary basins (Littke et al., 1998). Reworked organic matter content in soils and present lacustrine sediments not only gives evidence of past vegetal cover but can testify of the bedrock that feed the detrital supply (Di-Giovanni et al., 1999). Moreover, ancient reworked organic matter occurring in ice-sheets inferred an active role of palaeo-ice flow delivered to the North Atlantic Ocean (Hefter et al., 2017). In turn, reworked organic matter input in lower and middle members of the Middle Permian Gufeng Formation (continental platform, China) suggested the transgression which probably forced the supply of organic matter from soil to the basin (Kametaka et al., 2005; Takebe et al., 2007).

Studies on the inputs, transport and distribution of terrigenous $\mathrm{OM}$ are thus necessary to infer the quantity and composition of OM flowing into marine environments, particularly within continental margins where $>90 \%$ of organic carbon burial occurs (Berner, 1989; Hedges et al., 1994, 1997, 1999; Hedges and Keil, 1995; Aller et al., 1996). Various geochemical and petrographic approaches, e.g., vitrinite reflectance, Rock-Eval $T_{\max }$, and biomarker maturity ratios can be used to define the thermal maturity of organic matter (OM). Thermal 
Sample locations and age

\begin{tabular}{|c|c|c|c|c|c|c|}
\hline $\begin{array}{l}\text { Sample } \\
\text { symbol }\end{array}$ & Place/Town & Lithostratigraphic unit & $\begin{array}{l}\text { Series/ } \\
\text { Epoch }\end{array}$ & Stage/Age & $\begin{array}{c}\text { Structural } \\
\text { unit }\end{array}$ & $\begin{array}{r}\text { Lithology of } \\
\text { hosting rocks }\end{array}$ \\
\hline $\mathrm{E} 1$ & Kozy & Lhoty Fm. & $\mathrm{Cr}_{1} / \mathrm{Cr}_{2}$ & Albian-Cenomanian & $S$ & mudstone \\
\hline E2 & Bieśnik & Istebna Fm. & $\mathrm{Cr}_{2} / \mathrm{PI}$ & Senonian-Paleocene & $S$ & sandstone \\
\hline E3 & Bielsko-Biała & Lhoty Fm. & $\mathrm{Cr}_{1} / \mathrm{Cr}_{2}$ & Albian-Cenomanian & $S$ & sandstone \\
\hline E4 & Porąbka Uszewska & Lhoty Fm. & $\mathrm{Cr}_{1} / \mathrm{Cr}_{2}$ & Albian-Cenomanian & $\mathrm{S}$ & sandstone \\
\hline E5 & Sułkowice & Cisownica Shales & $\mathrm{Cr}_{1}$ & Valanginian-Hauterivian & $S$ & mudstone \\
\hline E6 & Ciężkowice & Istebna Fm. & $\mathrm{Cr}_{2} / \mathrm{PI}$ & Senonian-Paleocene & $S$ & sandstone \\
\hline $\mathrm{E} 7$ & Skrzydlna & Menilite Fm. & $\mathrm{OI}$ & Oligocene & $\mathrm{D}$ & sandstone \\
\hline E8 & Gorlice & Istebna Fm. & $\mathrm{Cr}_{2} / \mathrm{PI}$ & Senonian-Paleocene & $S$ & sandstone \\
\hline E9 & Międzybródź & Grodziszcze Fm. & $\mathrm{Cr}_{1}$ & Hauterivian-Aptian & $S$ & sandstone \\
\hline E10 & Kobielnik & Menilite Fm. & $\mathrm{Ol}$ & Oligocene & $\mathrm{D}$ & sandstone \\
\hline E11 & Rabe & Istebna Fm. & $\mathrm{Cr}_{2} / \mathrm{PI}$ & Senonian-Paleocene & $S$ & sandstone \\
\hline E12 & Bystre & Lhoty Fm. & $\mathrm{Cr}_{1} / \mathrm{Cr}_{2}$ & Albian-Cenomanian & $S$ & conglomerate \\
\hline E13 & Okocim & Grodziszcze Fm. & $\mathrm{Cr}_{1}$ & Hauterivian-Aptian & $S$ & sandstone \\
\hline E14 & Rożnów & Istebna Fm. & $\mathrm{Cr}_{2} / \mathrm{PI}$ & Senonian-Paleocene & $S$ & sandstone \\
\hline E15 & Żywiec & Cisownica Shales & $\mathrm{Cr}_{1}$ & Valanginian-Hauterivian & $S$ & mudstone \\
\hline E16 & Tresna & Godula Fm. & $\mathrm{Cr}_{2}$ & Cenomanian-Senonian & $\mathrm{S}$ & sandstone \\
\hline EG1 & Lanckorona & Grodziszcze Fm. & $\mathrm{Cr}_{1}$ & Hauterivian-Aptian & SS & sandstone \\
\hline EG2 & Nowe Rybie & Rybie Ss. & $\mathrm{Cr}_{2}$ & Upper Senonian & SS & sandstone \\
\hline EG3 & Żegocina & Grodziszcze Fm. & $\mathrm{Cr}_{1}$ & Hauterivian-Aptian & SS & conglomerate \\
\hline EG4 & Radziechowy & Szydłowiec Ss. & $\mathrm{PI}$ & Paleocene & SS & sandstone \\
\hline
\end{tabular}

Fm. - formation; Ss. - sandstones; $\mathrm{Cr}_{1}$ - Lower Cretaceous; $\mathrm{Cr}_{2}$ - Upper Cretaceous; PI - Paleocene; OI - Oligocene; D Dukla; S - Silesian; SS - Subsilesian

maturation designates changes in OM structure during heating of rock connected with generation of hydrocarbons. Thus, thermal maturity is one of the most important source rock properties and can be confirmed by quantitative and qualitative analyses of OM (Hunt, 1996).

The Outer Carpathians in Poland belong to the North Petroleum Province in Central Europe (Ulmishek and Klemme, 1990; Soták et al., 2001; Pawlewicz, 2006; Kotarba and Peryt, 2011). In the Outer Carpathians, Lower Cretaceous and Oligocene-Miocene strata are considered to be organic-rich source rocks (e.g., Koltun et al., 1995; Curtis et al., 2004; Kotarba and Koltun, 2006; Kotarba et al., 2007, 2013, 2014, 2017; Kosakowski et al., 2009; Kosakowski, 2013; Coric, 2015; Wendorff et al., 2017). Additionally, Mesozoic successions beneath the Carpathian overthrust, Paleozoic strata in the Carpathian Foredeep basement and Lower Paleozoic formations underlying the thrusted and folded Carpathian orogen have been deemed petroleum-generating sequences (Matolin et al., 2007; Więcław et al., 2011; Kosakowski et al., 2012). Apart from geochemical studies aimed at recognizing strata with hydrocarbon potential in the Carpathians and their vicinity, the petrographic characterization of the $\mathrm{OM}$ and its sedimentary environment has been studied. The OM in the Outer Carpathian deposits contains also redeposited CC from silt- to boulder size, thin vitrain layers or lenses and dispersed OM representing allochthonous terrestrial, and autochthonous marine sources (e.g., Turnau, 1970; Kotlarczyk, 1979; Wagner, 1992, 1996; Uziyuk and Shaynoga, 2016; Ziemianin, 2017, 2018; Górecka-Nowak et al., 2019; Wójcik-Tabol et al., 2019; Waliczek et al., 2019). The redeposited CC belonging to the Lower and Middle Pennsylvanian were supplied to the Outer Carpathian basin from cordilleras and from the area bordering the basin to the north (Turnau, 1970; Wójcik-Tabol et al., 2019). Two main source areas have been established for these, namely, the Upper Silesian Coal Basin and its continuation to the south and the coal basin underlying the eastern part of the Polish Carpathians (Bukowy, 1957; Kotlarczyk and Śliwowa, 1963; Wójcik-Tabol et al., 2019). Thus, Turnau (1970) suggested that these two areas formed one Precarpathian Coal Basin. In contrast, thin homogeneous vitrain coal-forming lenses and layers in clastic sediments reflect carbonization of terrestrial organic particles in the Outer Carpathian flysch basin (Zielińska, 2017).

The aim of this paper is to compare geochemical and petrographic indicators that point to the depositional environment and thermal maturity of the authigenic and allogenic organic matter from the Polish Outer Carpathian rocks (Table 1). Such description and comparison were done in various lithostratigraphic units of POC using different research techniques to underline differences in the detection of various types of organic matter depending on the analysis used.

For a more precise division of organic matter in this study, the following terms were used:

- planktonic organic matter (POM) represents hydrogen-rich material that originated from the marine ecosystem;

- terrigenous organic matter (TOM) represents terrestrial dispersed OM transported with rock detritus into the sedimentary basin prior to its coalification;

- coal clasts (CC) as eroded humic coal fragments older than the Outer Carpathian sediments.

Such division of organic matter was imposed by the significant differences in thermal maturity of different types of organic matter represent authigenic and allogenic sources of OM in the 
Carpathian rocks (e.g., Wagner, 1996; Zielińska, 2010; Bąk et al., 2015; Ziemianin, 2017, 2018).

\section{GEOLOGICAL SETTING}

The Outer Carpathians belong to the Carpathian mountain range forming a $\sim 1500 \mathrm{~km}$ long arc in Central and Eastern Europe (Fig. 1A). It is part of the Alpine orogenic belt of Mesozoic and Paleogene/Neogene age. The range is a fold-and-thrust belt with generally north vergence in the western part north-east to east vergence in the eastern part and southeast vergence in the southern part. In Poland, the Carpathians are subdivided into two domains, i.e., the Inner Carpathians (Triassic-Jurassic) and the Outer Carpathians (Jurassic-Neogene Plašienka, 2002; Oszczypko, 2006; Plašienka and Soták 2015). The border between the domains is the Pieniny Klippen Belt, a complex suture along which components of oceanic and continental lithosphere were subducted during Late Cretaceous and Early Miocene convergence (Birkenmajer, 1986; Golonka et al., 2006). The Outer Carpathians comprise elements of an accretionary wedge subdivided into nappes composed of Cretaceous to Paleogene strata as outlined in Figure 1B. All the nappes mainly involve clastic sediments (Jurassic-Lower Miocene). They are overthrusted onto Miocene strata of the Carpathian Foredeep (Oszczypko and Żytko, 1987 Oszczypko, 2004). The epi-Variscan Central European Platform and its cover form the basement of the Outer Carpathians. The depth to basement varies from $7000 \mathrm{~m}$ beneath the Carpathians to a few hundred metres at the fringes (Oszczypko, 2004; Králiková et al., 2016).

Most of the sediments of the Outer Carpathians are flysch-type consisting of alternating coarse-grained beds, i.e., conglomerates, sandstones, siltstones and, locally, limestones and marls of deep-marine origin. Most of the sediments were deposited at bathyal, presumably mostly upper bathyal, depths (Książkiewicz, 1975; Poprawa et. al., 2002). The area studied involves the Silesian, Sub-Silesian and Dukla nappes of Upper Jurassic-Paleogene age. The Silesian nappe consists of Upper Jurassic to Miocene and Sub-Silesian from Lower Cretaceous to Miocene rocks. Lithologically, the Silesian and Sub-Silesian nappes are very similar (Fig. 2) whereas, in Sub-Silesian strata, silty and marly rocks predominate. The Dukla nappe consists of mid-Cretaceous shales, Senonian to Eocene turbidites, and the Lower Oligocene Menilite Formation passing upwards into distal turbidites (Oszczypko, 2004). The Silesian nappe is the second largest nappe after the Magura nappe, whereas the Sub-Silesian nappe is exposed in tectonic windows in the Silesian nappe, and the frontal part of the Carpathian foreland (Leśniak and Waśkowska-Oliwa, 2001). The Dukla nappe is situated below the frontal Magura nappe and is also exposed in tectonic windows in it (Fig. 1B).

\section{SAMPLES AND METHODS}

\section{SAMPLES}

Twenty representative rock samples containing visible OM (sampling sites in Fig. 1) were collected from clastic rocks belonging to the Berrasian, Valanginian, Hauterivian, Barremian, Albian, Paleocene and Oligocene age (Table 1) in natural outcrops, quarries and riverbanks. Flysch deposits belonging to described age were investigated for sampling as typical redeposited CC - bearing rocks which were previously palynological described by Turnau (1970).

Special attention was paid to the presence of coal fragments in detrital forms, especially redeposited CC. Unfortunately most samples contained both various fractions of $\mathrm{CC}$ and TOM; consequently, distinguishing different genetic types of $\mathrm{OM}<2 \mathrm{~mm}$ during sampling was impossible. Therefore, all organic matter contained in the samples was analysed.

\section{PETROGRAPHY}

Samples were prepared as polished blocks according to the procedures in ISO 7404-2 (2009). Maceral identifications were carried out in reflected white light and fluorescent blue light using ICCP terminology (ICCP, 1998, 2001; Pickel et al., 2017). Random reflectance $\left(R_{r}, \%\right)$ was measured in oil immersion according to ISO 7404-5 (2002) at 50 points using an optical Axio Imager $A 2 m$ microscope.

\section{GEOCHEMISTRY}

ROCK-EVAL PYROLYSIS

The screening pyrolysis was completed with a Vinci Technologies Rock-Eval 6 Turbo apparatus in Bulk Rock method using the Basic cycle. This analysis consisted of two steps. Firstly, a crucible with 30-50 mg of powdered rock sample was loaded into a pyrolytic oven in which a nitrogen atmosphere (flow of $100 \mathrm{ml} / \mathrm{min}$ ) was heated from $300^{\circ} \mathrm{C}$ (3 min isothermal) to $650^{\circ} \mathrm{C}$ at $25^{\circ} \mathrm{C} / \mathrm{min}$. The generated gases were directed to a flame ionization detector (FID) for determination of free hydrocarbon contents (released at isothermal $300^{\circ} \mathrm{C}-S_{1}$ peak), residual hydrocarbon contents (released at $300-650^{\circ} \mathrm{C}-S_{2}$ peak) and temperature of maximum of $S_{2}$ peak $\left(T_{\max }\right)$ and to an infra-red cell (IR) for determination of $\mathrm{CO}$ and $\mathrm{CO}_{2}$ produced during decomposition of $\mathrm{OM}$ and carbonates $\left(S_{3}, S_{3}, S_{3 c o}\right.$ and $S_{3^{\prime} \text { co }}$ peaks). Each pyrolyzed sample was then moved to an oxidation oven where it was heated in air $(100 \mathrm{ml} / \mathrm{min})$ from $300^{\circ} \mathrm{C}$ (1 min isothermal) to $850^{\circ} \mathrm{C}$ at $20^{\circ} \mathrm{C} / \mathrm{min}(5 \mathrm{~min}$ isothermal at final temperature). The $\mathrm{CO}$ and $\mathrm{CO}_{2}$ produced $\left(S_{4}, S_{4 C O}\right.$ and $S_{5}$ peaks) were determined using an IR detector. Indices used for quantitative, qualitative and maturity evaluation of $\mathrm{OM}$ were calculated, i.e., pyrolytic (PC, wt.\%), residual (RC, wt.\%), total organic carbon content (TOC, wt.\%), production index $\left(\mathrm{PI}=\mathrm{S}_{1} /\left(\mathrm{S}_{1}+\mathrm{S}_{2}\right)\right)$, hydrogen index $\left(\mathrm{HI}=100 * \mathrm{~S}_{2} / \mathrm{TOC}, \mathrm{mg} \mathrm{HC} / \mathrm{g}\right.$ TOC), oxygen index (OI $\left.=100^{*} \mathrm{~S}_{3} / \mathrm{TOC}, \mathrm{mg} \mathrm{CO} / \mathrm{g} \mathrm{TOC}\right)$, and mineral carbon content (MINC, wt.\%). Analytical details are as in Lafargue et al. (1998).

SOLVENT EXTRACTION

Prior to extraction, the samples were air-dried for $48-72 \mathrm{~h}$ at room temperature $\left(\sim 22^{\circ} \mathrm{C}\right)$ and powdered in a rotary mortar. After powdering, 5-8 $\mathrm{g}$ aliquots of each were extracted with dichloromethane (DCM) in a Dionex 350 Accelerated Solvent Extractor (Thermo Scientific) at $70^{\circ} \mathrm{C}$ in $34 \mathrm{ml}$ stainless steel cells $(p=10 \mathrm{Mpa}$; solvent flow $=70 \mathrm{ml} / \mathrm{min}$ ). Solvent was evaporated at room temperature and dried extracts weighed to calculate extraction yields (wt.\%). The dry residue was diluted in $1.5 \mathrm{ml}$ of DCM and analysed by GC-MS. All solvents and reagents were of analysis grade (Avantor Performance Materials Poland S.A.). 

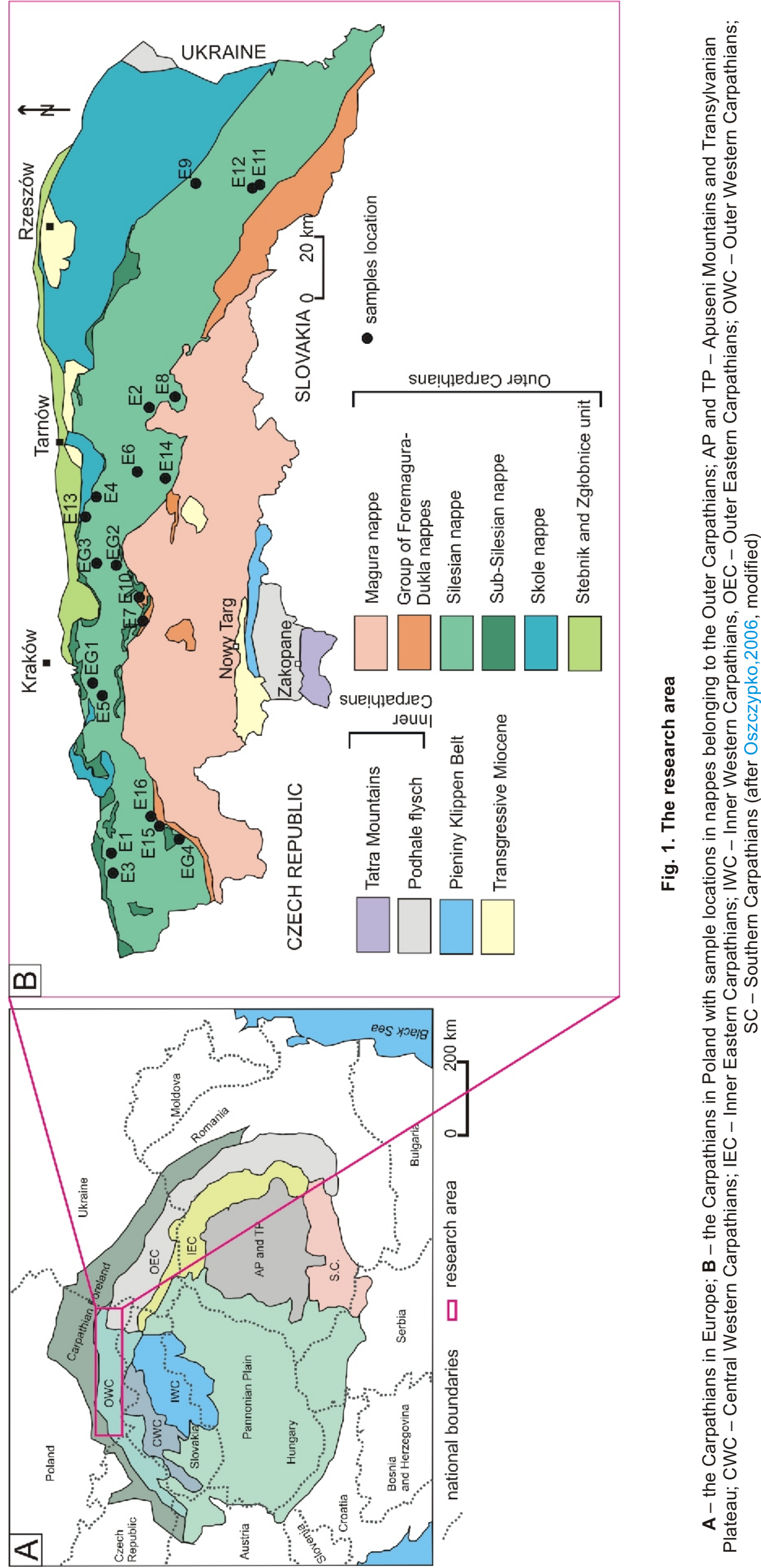


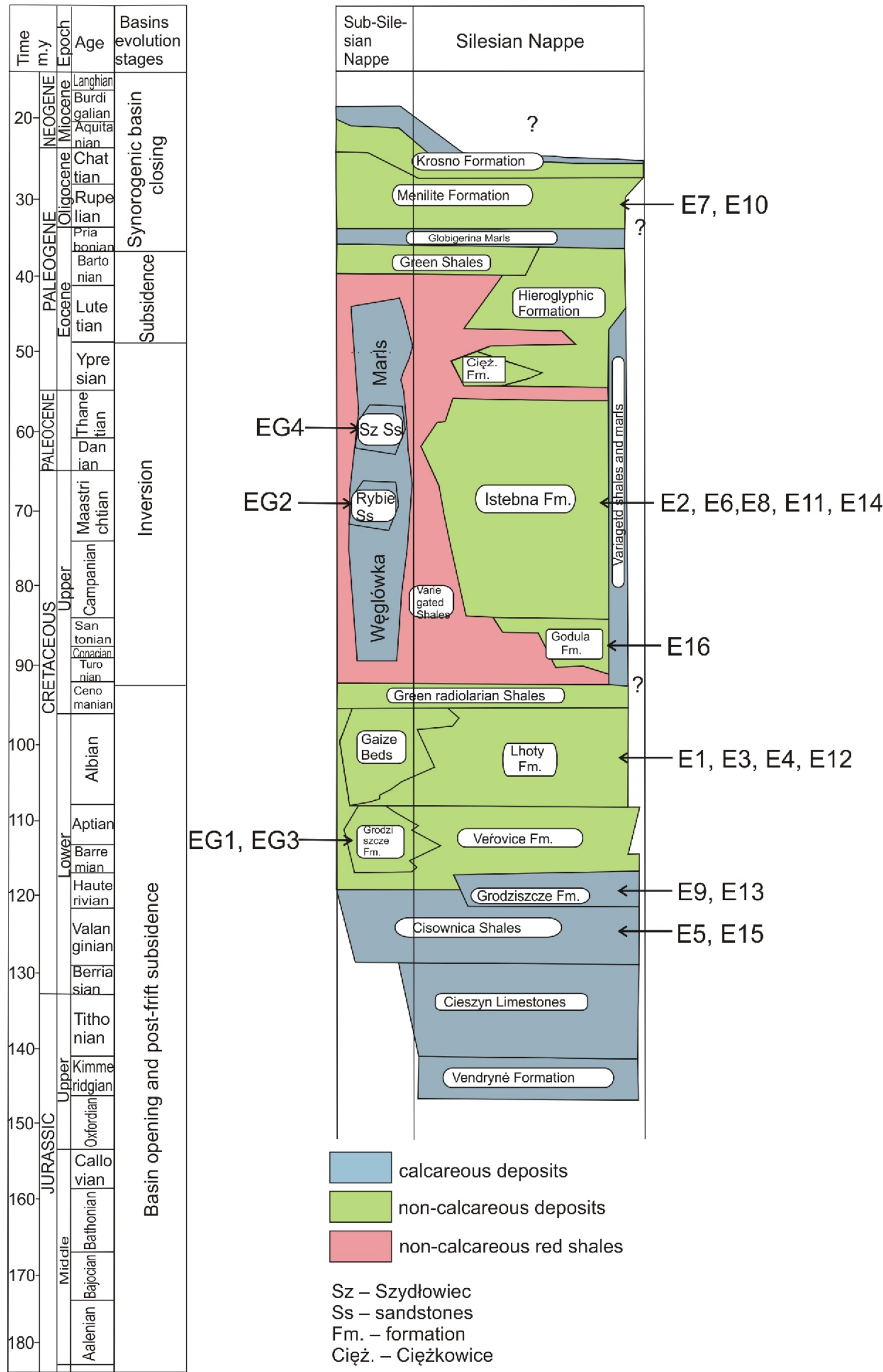




\section{GAS CHROMATOGRAPHY-MASS SPECTROMETRY}

An Agilent gas chromatograph 6890 with a HP-5 column $(60 \mathrm{~m} \times 0.25 \mathrm{~mm}$ i.d. $)$ coated with a $0.25 \mu \mathrm{m}$ stationary phase film and coupled with an Agilent Technology mass spectrometer 5973 was used. The experimental conditions were as follows: carrier gas - He; temperature $-50^{\circ} \mathrm{C}$ (isothermal for $2 \mathrm{~min}$ ); heating rate - up to $175^{\circ} \mathrm{C}$ at $10^{\circ} \mathrm{C} / \mathrm{min}$, to $225^{\circ} \mathrm{C}$ at $6^{\circ} \mathrm{C} / \mathrm{min}$ and, finally, to $300^{\circ} \mathrm{C}$ at $4^{\circ} \mathrm{C} / \mathrm{min}$. The final temperature $\left(300^{\circ} \mathrm{C}\right)$ was held for 20 minutes. The mass spectrometer was operated in the electron impact ionization mode at $70 \mathrm{eV}$ and scanned from 50-650 da. Data were acquired in a full scan mode and processed with the Hewlett Packard Chemstation software. The compounds were identified by using their mass spectra, comparison of peak retention times with those of standard compounds, interpretation of MS fragmentation patterns and literature data (Philp, 1985; MSD, 2012). Geochemical parameters were calculated using peak areas acquired in the manual integration mode.

\section{RESULTS}

\section{ORGANIC PETROGRAPHY}

Twenty rock samples were analysed, two of which (E9, EG4) contained insufficient OM for petrographic analysis. The petrographic analyses revealed two types of OM, namely, CC and TOM (Appendix 1). Samples E1, E2, E3, E4, E6, E7, E11, E12, E13, E14, E15, E16 and EG3 contain both CC and TOM. Samples E5, E8, E10 and EG2 contain CC only, and EG1, TOM only (Appendix 1*).

The CC is characterized by wide range of macerals distribution. In contrast, maceral forms in TOM hosted in the sediments are few.

The vitrinite maceral group, represented by collotelinite, telinite, collodetrinite and gelinite dominates in CC (Figs. 3 and 4). From the liptinite maceral group, sporinite, cutinite, resinite and liptodetrinite macerals occur (Figs. 3 and 4). Predominantly, fusinite and semifusinite and, less commonly, inertodetrinite, macrinite, and micrinite represent the intertinite maceral group (Figs. 3 and 4). Massive chars in some samples with $\mathrm{CC}$ are isotropic, yellowish in colour, and have high reflectance. Some of these show small pores related to devolatilisation (Fig. 4).

The maceral composition of TOM shows no such variety; only collotelinite, vitrodetrinite, gelinite, inertodetrinite occur and, in E16 only, probably solid mosaic bitumen (Nowak 2019). Solid bitumen fits the sandstone pores and it is characterized by heterogeneous structure (various shades of grey), very weak fluorescence and $R_{r}=1.21 \%$. Pyrite, as framboids and euhedral crystals, is an associate of both forms of organic matter (Fig. 4). In CC, pyrite occurs mainly as framboids. It is rare as single crystals impregnating coal macerals. In TOM, pyrite commonly impregnates the margins of vitrinite particles or occurs as accumulations of framboids (Fig. 4). The typical land-plant maceral composition of both OM types confirms their terrigenous origin.

Thermal maturity expressed by vitrinite reflectance $R_{r}$ ranging from $0.53-1.52 \%$ in CC points to an early-mature to overmature stage of organic matter transformation (Appendix 1).
These $R_{r}$ values correspond to high-volatile and low-volatile bituminous coal rank according to the ISO/DIS 11760 classification. The TOM is immature and early-mature $\left(R_{r}=0.41-0.67 \%\right)$ indicative of subbituminous $B$ to high-volatile bituminous coal.

The variability in thermal maturity of the $\mathrm{OM}$ is clear in reflectograms in which vitrinite reflectance data show a variable distribution, depending on the percentage of particular types of organic matter in sample. If sample contains only or mostly CC, the reflectogram is monomodal (e.g., E8, E12); both types, the reflectogram is bimodal (e.g., E4); if contains mostly dispersed TOM, the reflectogram shows trimodal $R_{r}$ distribution (E7) as shown in Figure $5 A-D$. It is evident that the OM originated from a variety of sources. If $R_{r}$ is measured only on grains with typical $\mathrm{CC}$ qualities, the distribution of values obtained is monomial (see comparison in Fig. 5E, F).

\section{GEOCHEMISTRY}

ROCK-EVAL DATA

The samples are highly variable in OM content. The TOC varies from 0.05 in EG1 $(O)$ sample to 59.8 wt.\% in E8 (A) sample, but is typically $<1$ wt. \% (Appendix 2 ). The concentration of organic carbon partly depends on the origin and form of dispersion of OM. Sample E8 with the highest TOC (almost 60 wt.\%) is a piece of coal (CC) separated from sandstone rock, but other rocks rich in TOC contain multi-sourced OM (CC and POM or CC, TOM and POM). In samples poor in organic carbon all types of OM were identified (Appendix 2). The strong correlation of OM concentration with $T_{\max }$ values is visible; organic material occurring in high concentrations (TOC $>1 \mathrm{wt} . \%$ ) is immature or mature (oil window range) with $T_{\max }$ values varying from 422 to $454^{\circ} \mathrm{C}$ whereas for samples poor in OM (TOC $<0.54$ wt. \%) $T_{\max }$ values are $>490^{\circ} \mathrm{C}$ (Fig. $6 \mathrm{~A}$ ). The elevated $T_{\max }$ temperatures are result of strong oxidation of organic material and correlate with high values of oxygen index (Fig. 6B), but the possible influence of carbonate decomposition on Ol values, especially for mineral carbon-rich samples, is not excluded (Appendix 2). The erroneous (overstated) maturity assessment of weathered CC were reported earlier by e.g., Copard et al. (2002). The abnormally high $T_{\max }$ temperatures were also described for weathered fossil organic matter in outcrop profiles by Graz et al. (2011). The OM occurring in coal piece (sample E8), due to small contact surface with oxidizing media is resistant to oxidation processes and therefore shows low maturity. Small particles of OM in organic-poor samples have relatively high contact surface and therefore they are oxidized to a much greater extent. Correct determination of the genetic type of OM is possible only for no-oxidized samples; low hydrogen-index values of these samples indicate the presence of gas-prone Type-III kerogen (Fig. 7). Due to the probable at least partial weathering also of these samples, the original values of the hydrogen index were higher (Copard et al., 2006) and therefore presence of the hydrogen-rich kerogen Type-II or -I is not excluded. No clear relationship between the source of $\mathrm{OM}$ and the hydrogen index values is observed (Appendix 2 and Fig. 7). Examples of samples containing weathered organic material are presented in Figure $8 \mathrm{~A}-\mathrm{C}$. The multilobed $\mathrm{S}_{2}$ peaks are result of different range of OM oxidation (Copard et al., 2006). 

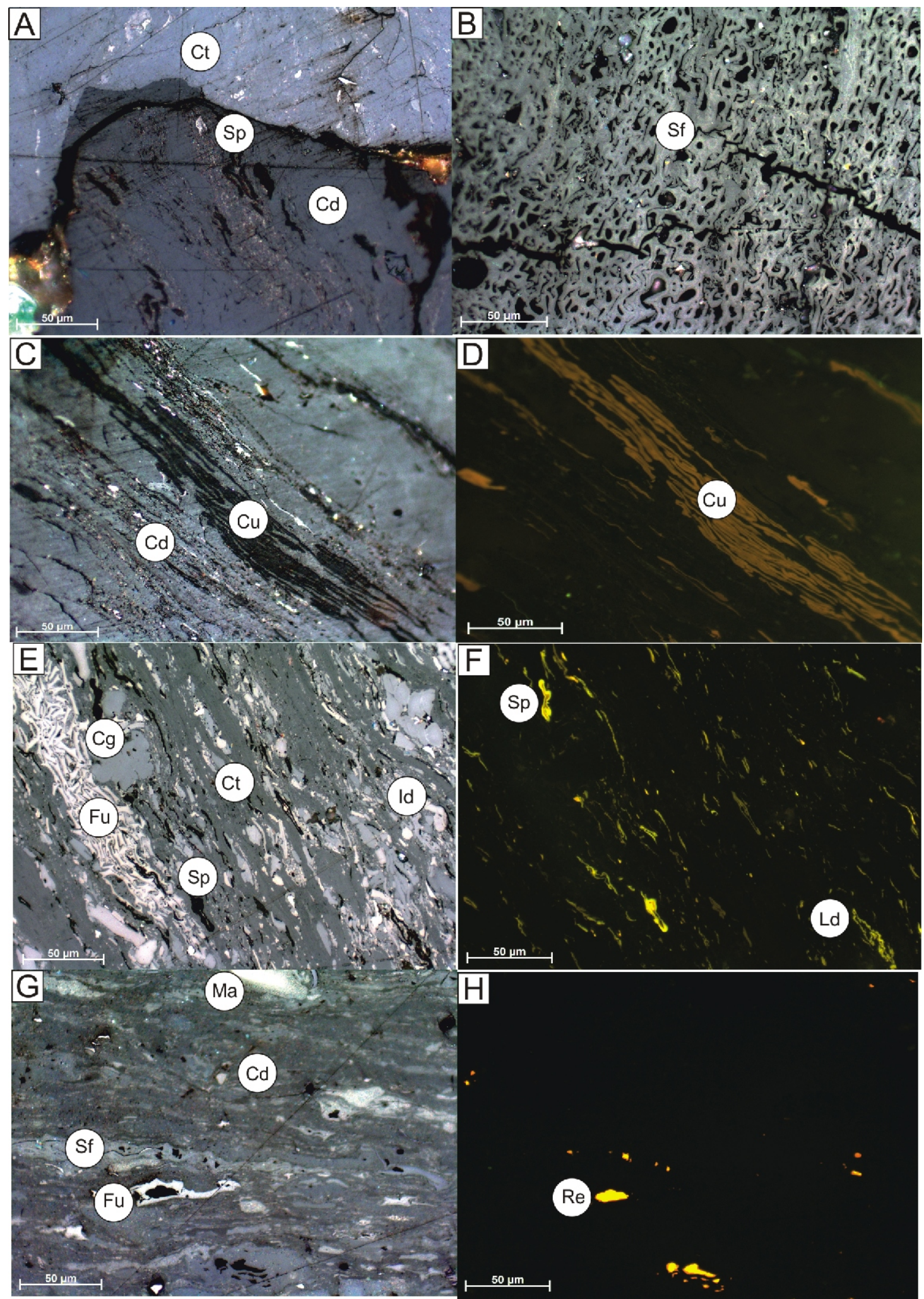

Fig. 3. Microphotographs of organic matter

A - variation in rank and petrographic composition of CC; higher rank of collotelinite $(\mathrm{Ct})$ in upper part of photo, lower rank of collodetrinite $(\mathrm{Cd})$ with sporinite $(\mathrm{Sp})$ in lower part of photo, sample E10, oil immersion, reflected light; B - semifusinite (Sf) structure with empty window cells, CC - sample E6, oil immersion, reflected light; C - collodetrinite (Cd) and cutinite (Cu), CC - sample EG2, oil immersion, reflected light; D - cutinite $(\mathrm{Cu})$ particles visible in fluorecscent light, CC - sample EG2, same view as in C; $\mathbf{E}$ - trimacerite with collotelinite (Ct), corpogelinite $(\mathrm{Cg})$, fusinite $(\mathrm{Fu})$, inertodetrinite (Id) and sporinite (Sp), CC - sample E8, oil immersion, reflected light; $\mathbf{F}$ - macerals of the liptinite group, sporinite (Sp) and liptodetrinite (Ld), CC - sample E8, fluorescent light, same view as in E; G - trimacerite with collodetrinite (Cd), semifusinite (Sf), fusinite (Fu) and macrinite (Ma), CC - sample E12, oil immersion, reflected light; $\mathbf{H}$ - resinite (Re) visible in fluorescent light, CC - sample E12, same view as in G 


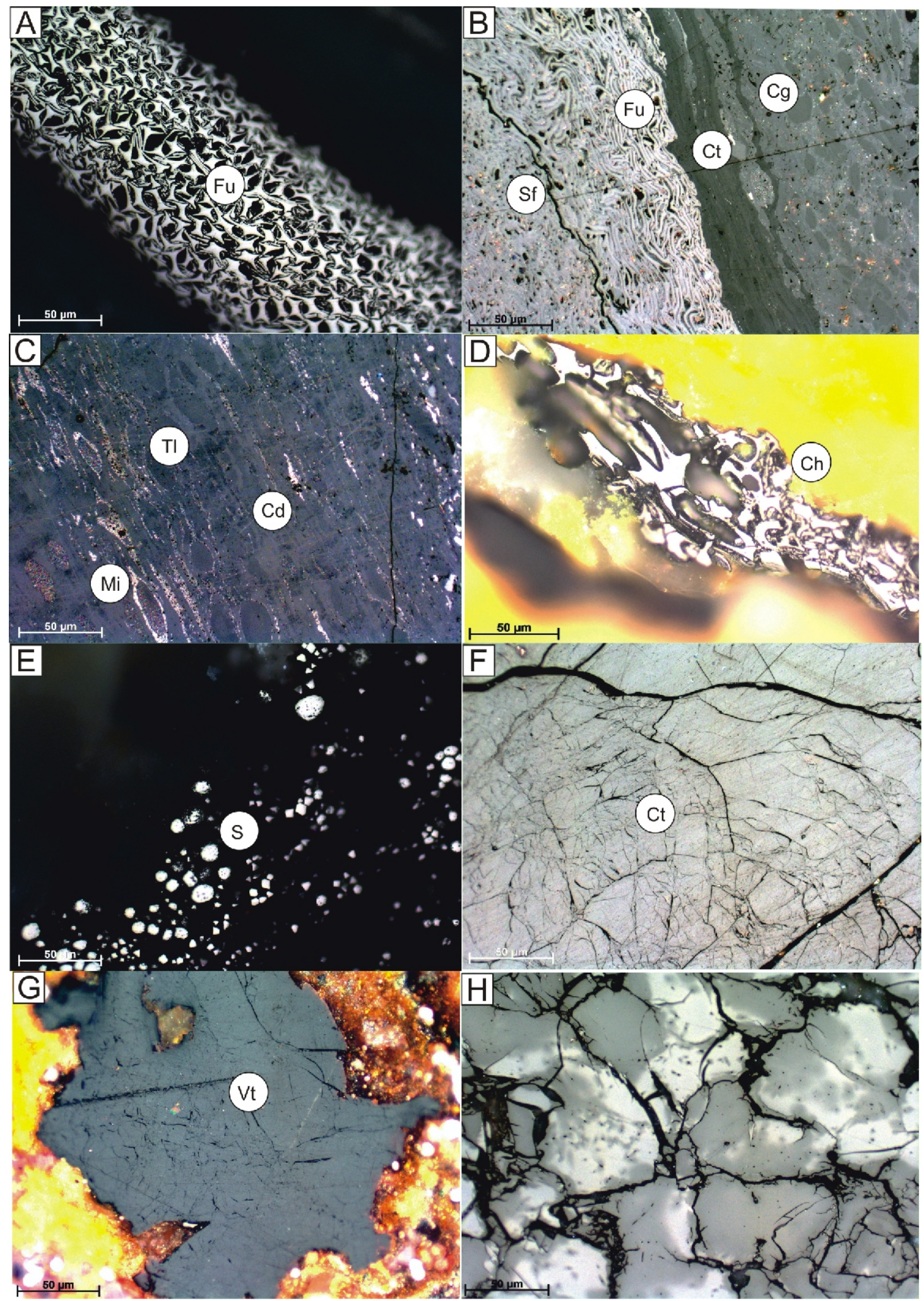

Fig. 4. Microphotographs of organic matter

A - cracked particle of fusinite (Fu), CC - sample EG2, oil immersion, reflected light; $\mathbf{B}$ - dimacerite with collotelinte (Ct), corpogelinite (Cg), semifusinite (Sf) and fusinite ( $\mathrm{Fu}$ ), $\mathrm{CC}$ - sample E8, oil immersion, reflected light; $\mathbf{C}$ - micrinite (Mi) macerals occurring in telinite cells (TI) structure with transition into collodetrinite (Cd), CC - sample E8, oil immersion, reflected light; D - massive chars (Ch) in CC, sample E8, oil immersion, reflected light; $\mathbf{E}$ - framboidal and euhedral crystals of pyrite (S) in mineral setting, sample E11, oil immersion, reflected light; $\mathbf{F}$ cracked collotelinite (Ct), CC - sample E10, oil immersion, reflected light; G - vitrinite (Vt) particle, sample E10, oil immersion, reflected light; H - solid bitumen, sample E16, oil immersion, reflected light 

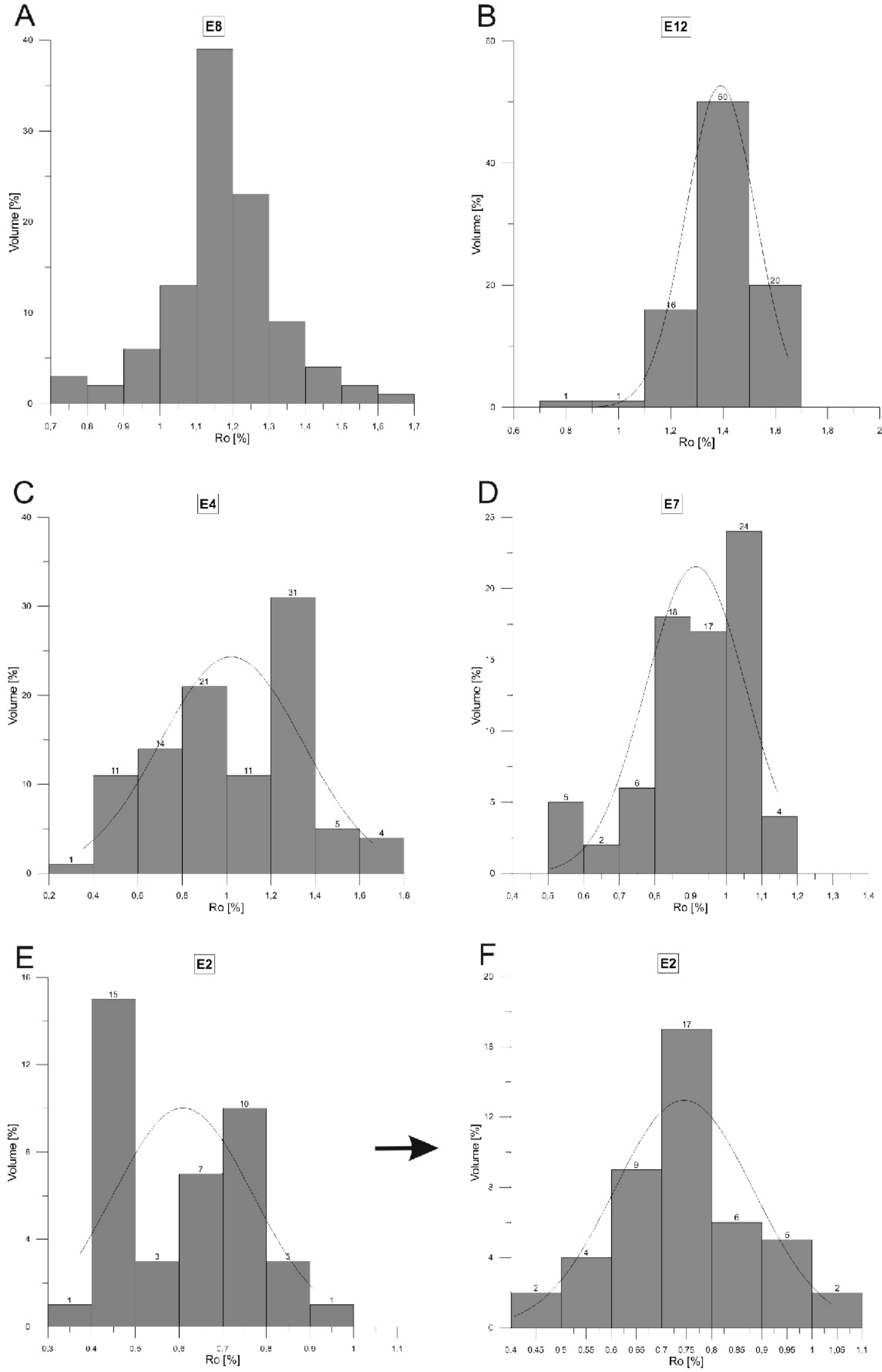

Fig. 5. Random vitrinite reflectograms

A, B - reflectograms of selected samples (E8 - CC, E12 - mostly CC) with monomodal distribution; C - reflectogram of sample (E4 - CC +TOM) with bimodal distribution; $\mathbf{D}$ - reflectogram of sample E7 (mostly TOM) with trimodal distribution; E, F - comparison of random vitrinite reflectograms involving all vitrinite-particle measurements in CC and TOM (left side) and measurements on vitrinite particles in CC only (right side) in the same sample 

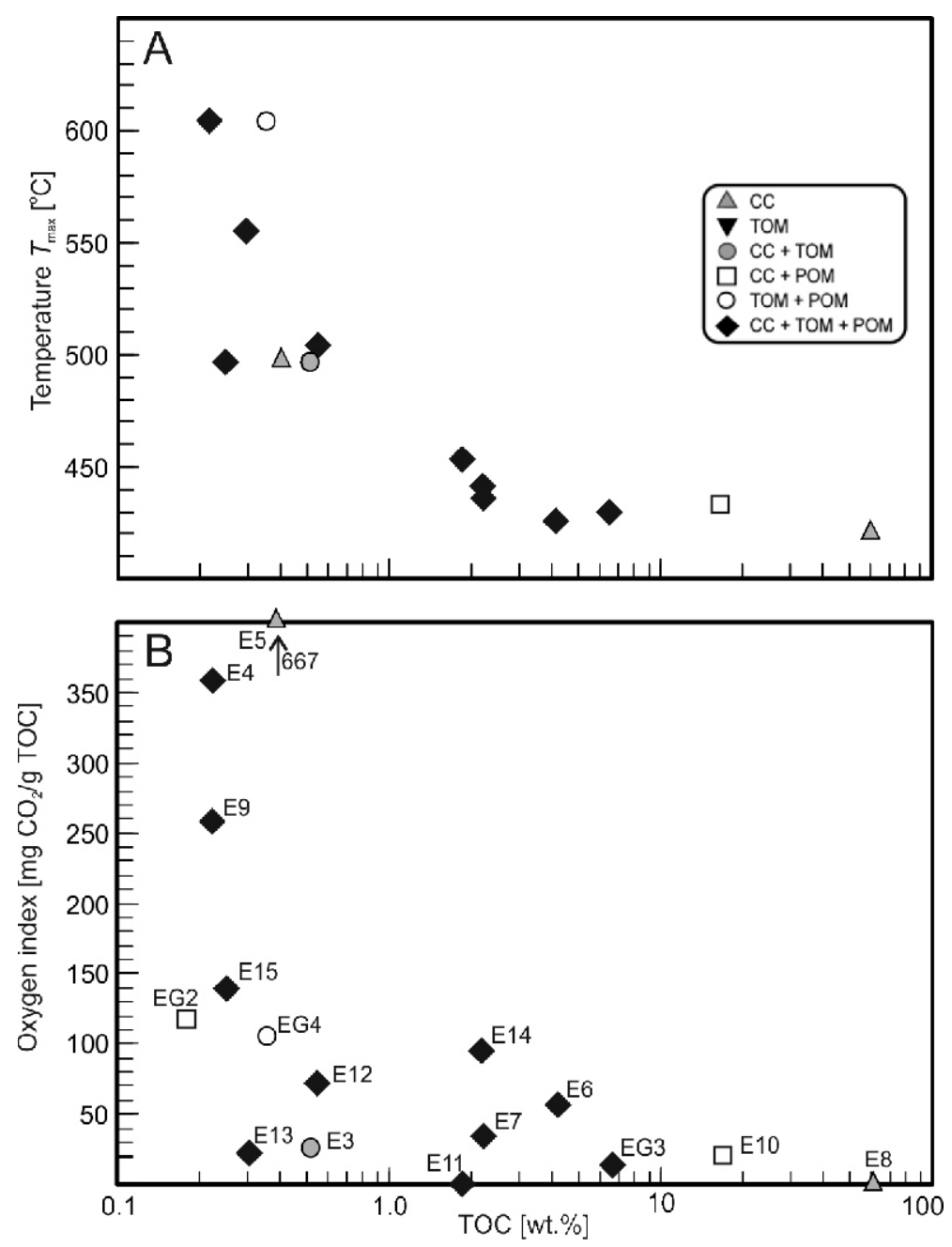

Fig. 6. Correlation of $T_{\max }$ temperature (A) and oxygen index (B) with total organic carbon content (TOC)

CC - coal clasts; TOM - terrigenous organic matter; POM - planktonic organic matter

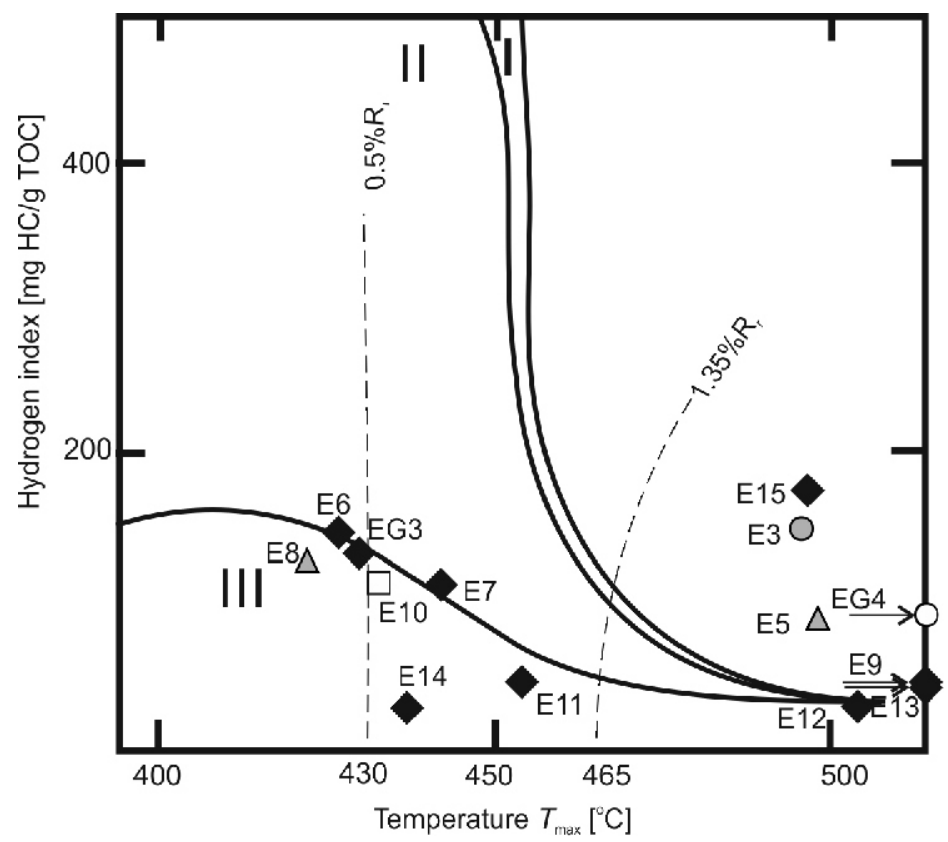

Fig. 7. Hydrogen index versus $T_{\max }$ temperatur Maturation paths for kerogens after Espitalié et al. (1985) 

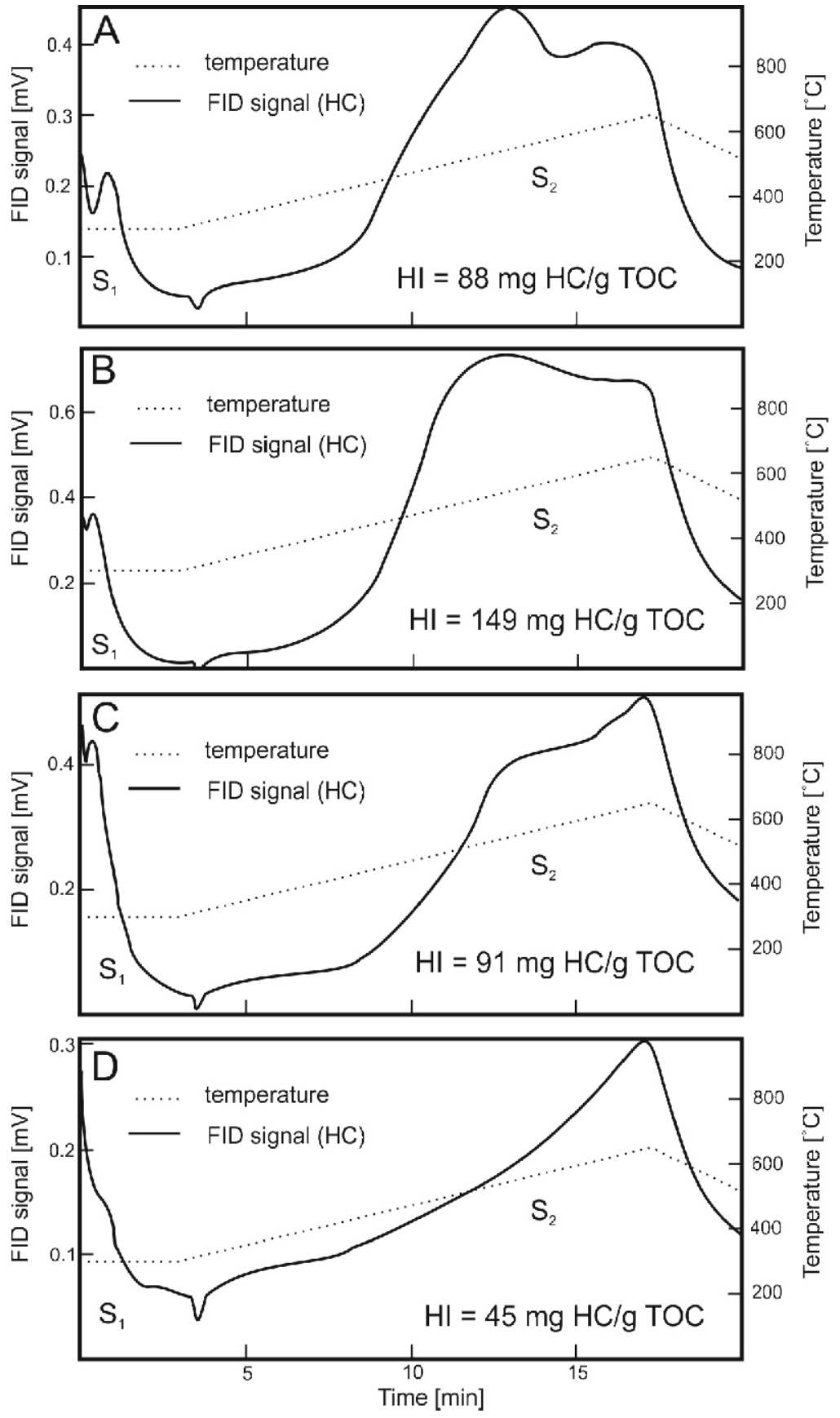

Fig. 8. Examples of pyrograms resulting from Rock-Eval analysis of sample E5 (A) (A), sample E3 (O) (B), sample EG4 (O) (C) and sample E9 (४) (D)

$\mathrm{S}_{1}$ - free hydrocarbons released during isothermal heating at $300^{\circ} \mathrm{C}$; $\mathrm{S}_{2}-$ residual hydrocarbons generated during thermal decomposition of kerogen from $300-650^{\circ} \mathrm{C}, \mathrm{HI}-$ hydrogen index, $\mathrm{HC}$ - hydrocarbon

BIOMARKER AND AROMATIC HYDROCARBONS DISTRIBUTION

Extract yields range from $0.003(\mathrm{E} 12 ; \diamond)$ to $0.735(\mathrm{E} 8 ; \Delta)$; the average is $0.018 \mathrm{wt} . \%$. The groups of aliphatic hydrocarbons and aromatic compounds identified in the extracts are $n$-alkanes $(m / z=71)$, acyclic isoprenoids $(m / z=71)$, steranes $(m / z=217)$ and tri-, and pentacyclic triterpanes $(m / z=191)$. Aromatic hydrocarbons together with their aliphatic derivatives include compounds from naphthalene $(\mathrm{m} / \mathrm{z}=128)$ to 5 -ring PAHs.
$n$-Alkanes comprise compounds in the range $n-\mathrm{C}_{12}-n-\mathrm{C}_{36}$. The most typical range is $n-C_{16}-n-C_{35}$. Generally, three types of distributions can be distinguished (Fig. 9):

1. Monomodal distribution with a maximum at $n-\mathrm{C}_{19}-n-\mathrm{C}_{20}$ with a smooth distribution outline (no odd-over even predominance); samples with two or three different OM sources: EG2 $(\square)$, EG4 $(O)$, E11 $(\bullet)$, E15 $(\diamond)$, and possibly also E7 $(\diamond)$ fall in this group. This distribution is like that shown by crude oils of planktonic origin deriving from mature kerogen Type-I or II. 


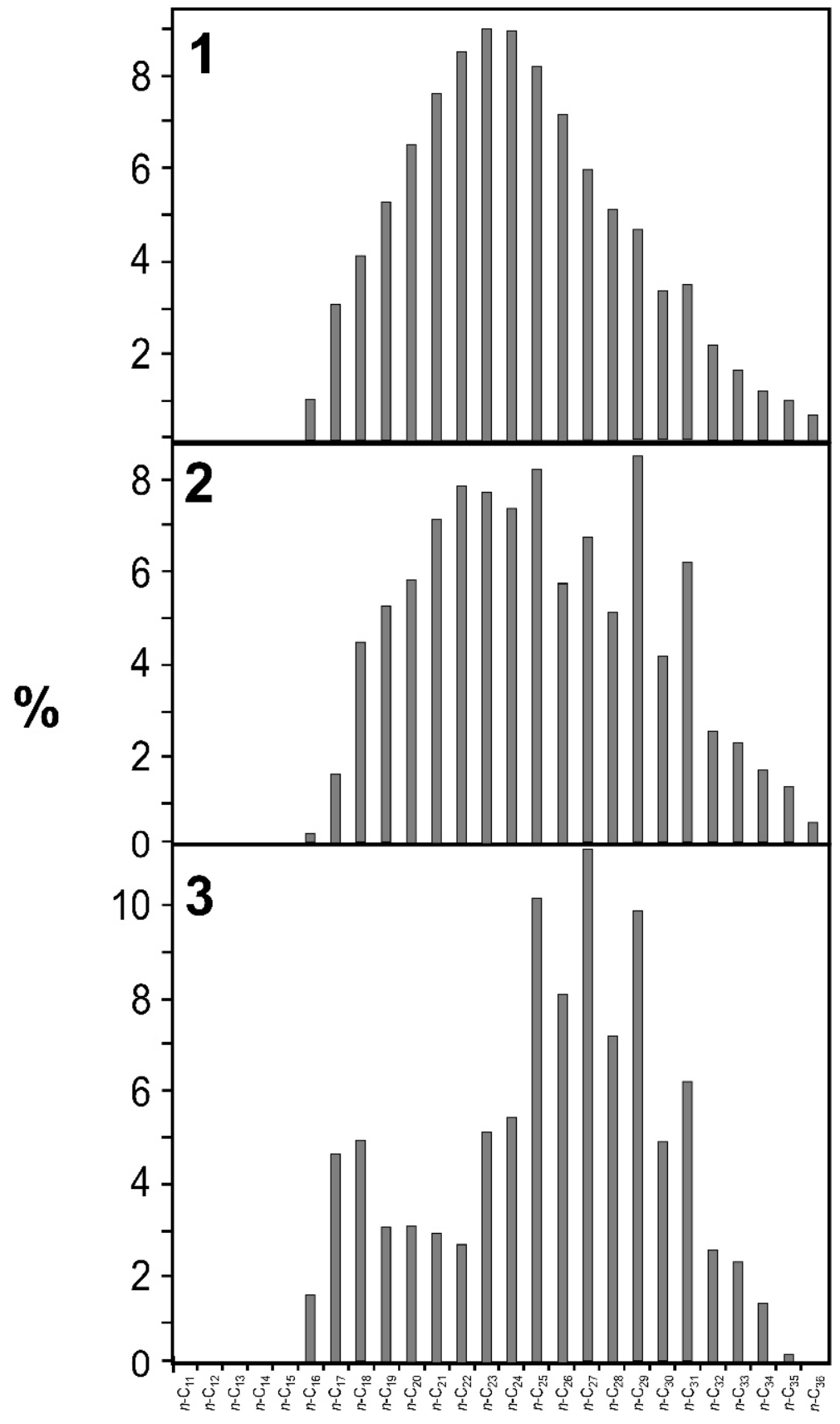

Fig. 9. $n$-Alkane distribution types in EG2 ( $\square)(1)$, E3 (๑) (2) and E6 (•) (3)

These samples usually show almost equal contents of long-chain and short-chain $n$-alkanes ( $\Sigma 2 / \Sigma 1$ in Appendix 3$)$.

2. Monomodal with odd-over-even carbon atom predominance in the distribution ((samples predominantly with terrestrial origin (CC and TOM): E3; $O$, E5; $\Delta, \mathrm{E} 8 ; \Delta, \mathrm{E} 16$; $\bullet$, and $\mathrm{EG} 1 ; \boldsymbol{\nabla}$. The maximum is at $n-\mathrm{C}_{27}-n-\mathrm{C}_{29}$ and the distribution usually reflects partial removal of lighter compounds, possibly due to water-washing/weathering and/or biodegradation (E16; $\diamond, E G 1 ; O)$. This distribution is indicative of kerogen Type-III of terrestrial origin, with thermal maturity corresponding to $R_{\mathrm{o}}$ of $\sim 0.7-0.9 \%$. Most of these samples show a marked predominance of long-chain over short-chain $n$-alkanes as shown by, e.g., $\Sigma 2 / \Sigma 1$ values of 10.22 and 15.47 from E8 $(\Delta)$ and E16 $(\diamond)$, respectively (Appendix 3 ), and reflecting a high input from cuticular waxes.
3. Bimodal with two distribution maximums at $n-\mathrm{C}_{19}-n-\mathrm{C}_{20}$ and $n-\mathrm{C}_{27}-n-\mathrm{C}_{29}$, with a distinctive odd-over-even carbon atom predominance. This distribution type, the most common in the sample set, was found in the EG3 $(\bullet), \mathrm{E} 1(\bullet), \mathrm{E} 2(\bullet), \mathrm{E} 4(\bullet)$, E6 $(\diamond)$, E9 $(\diamond)$, E10 $(\square)$ and E12-14 $(\diamond)$ extracts. This distribution is, most probably, due to overlapping of distributions (1) and (2), i.e., the mixing of OM mostly of all three (CC, TOM and POM) different sources in one sample (Fig. 10).

The first of the sources has the characteristics of mature, planktonic crude oil derived from kerogen Type-I or II (POM). The characteristics of the second match those of bituminous coals and kerogen Type-III (CC and TOM); they reflect dispersed coal material similar to Carboniferous, Upper Silesian bituminous coals redeposited in the hosting sediments (Kotarba and Clayton, 2003; Fabiańska et al., 2013). As E8 (A) is a pure 


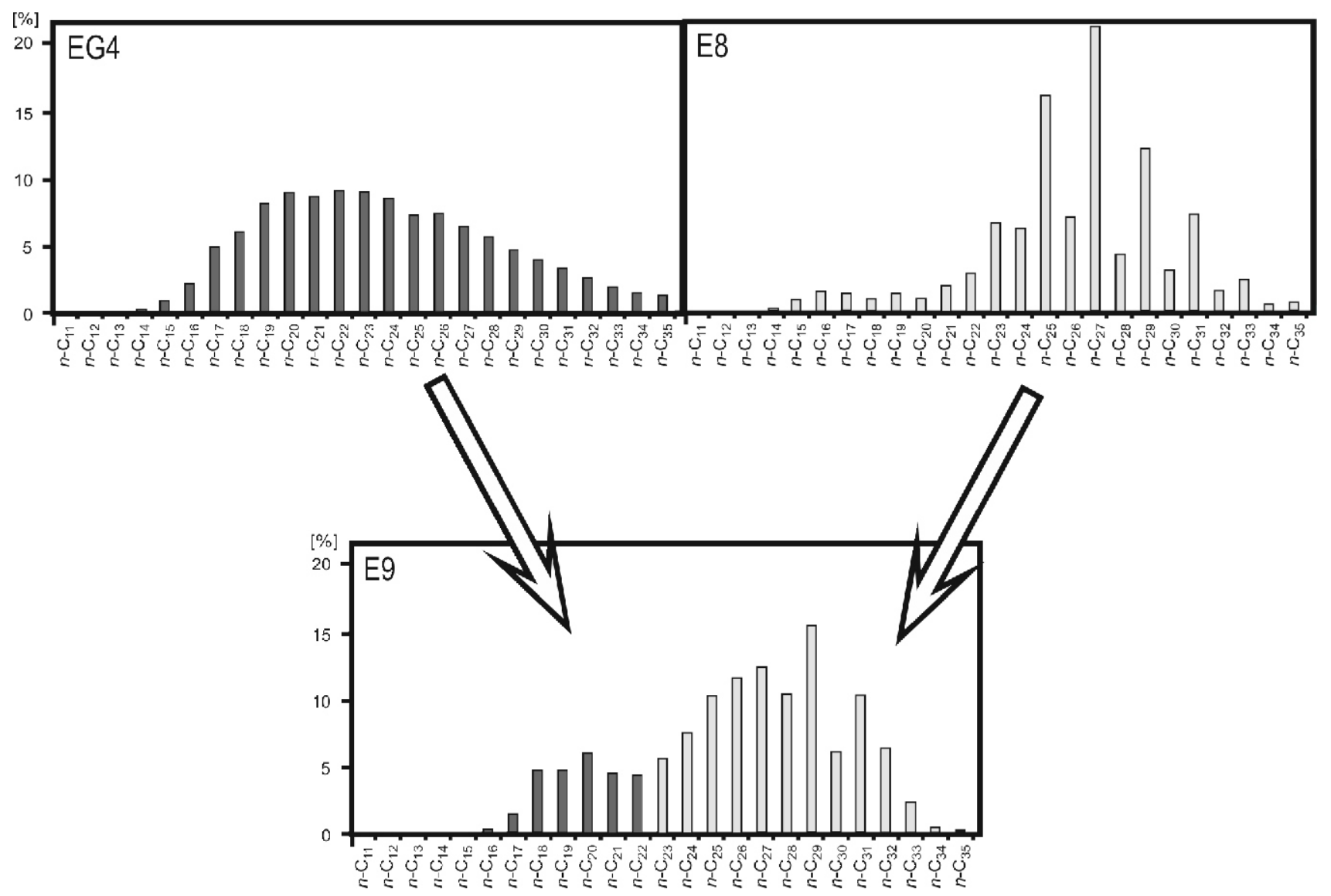

Fig. 10. Overlapping of $n$-alkane distribution types

redeposited $\mathrm{CC}$ showing the characteristics of $\mathrm{OM}$ derived from terrestrial plants (kerogen Type-III) only, it is used here as the reference sample to compare the extent of coal-material input.

The degree of CC and TOM input is well seen in the $\mathrm{Pr} / n-\mathrm{C}_{17}$ versus $\mathrm{Ph} / n-\mathrm{C}_{18}$ diagram (Fig. 11) where EG3 $(\bullet)$, E5 $(\Delta)$, E8 $(\boldsymbol{\Delta})$, E10 $(\square)$ and E11 ( ) plot in the field of coal and kerogen Type-III, and EG1 (O), EG2 ( $\square)$, EG4 (O), E1(•), E7 $(\diamond)$, E15 $(\diamond)$ and E16 $(\diamond)$ in that of kerogen Type-II; the latter were deposited in a reducing sedimentary environment. The

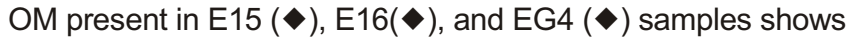
features of extremely high thermal maturity and/or extreme oxidation due to transport though all OM in this sample sub-set (I) is more mature than that in those of terrestrial origin. Samples showing higher inputs of $\mathrm{CC}$ and TOM plot in the intermediary field of kerogen Type-II/III and show the intermediary coalification stage on Figure 11. $\mathrm{Pr} / \mathrm{Ph}$ values vary widely from 0.10 (EG1; O) to 5.54 (E8; $\triangle$ ). $\mathrm{Pr} / \mathrm{Ph}$ values of $\sim 2-5$ are common in gas-prone kerogen Type-III and coals (Didyk et al., 1978). It seems that in samples EG3 $(\diamond)$, E6 $(\diamond)$, E8 $(\Delta)$, E10 $(\square)$, E11 $(\diamond)$ and possibly E14 $(\diamond)$ terrestrial material (CC and TOM) dominates resulting in increase of $\mathrm{Pr} / \mathrm{Ph}$ and Carbon Preference Index values (CPI; Appendix 3).

Pentacyclic triterpanes $(m / z=191)$ show two distribution types (Fig. 12):

1. The longer type reaching up to pentakishomohopanes $\left(\mathrm{C}_{35}\right)$ occurs in samples E1 $(\bullet), \mathrm{E} 7(\diamond), \mathrm{E} 9(\diamond), \mathrm{E} 10(\square), \mathrm{E} 15$ $(\diamond)$, EG2 $(\square)$, EG3 $(\diamond)$ and EG4 $(\bigcirc)$. In some cases, elevated

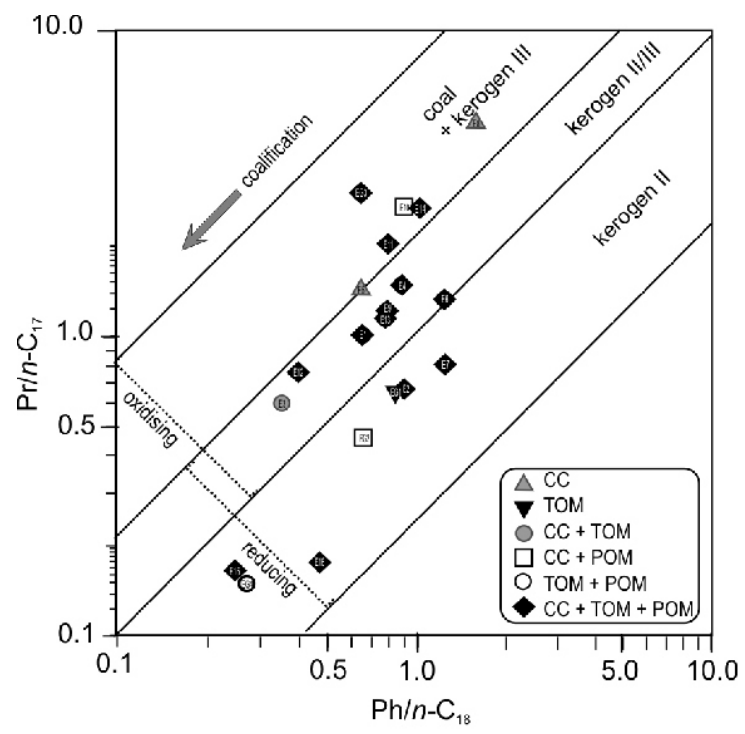

Fig. 11. $\mathrm{Pr} / n-\mathrm{C}_{17}$ versus $\mathrm{Ph} / n-\mathrm{C}_{18}$ plot (genetic fields after Shanmugam, 1985) 


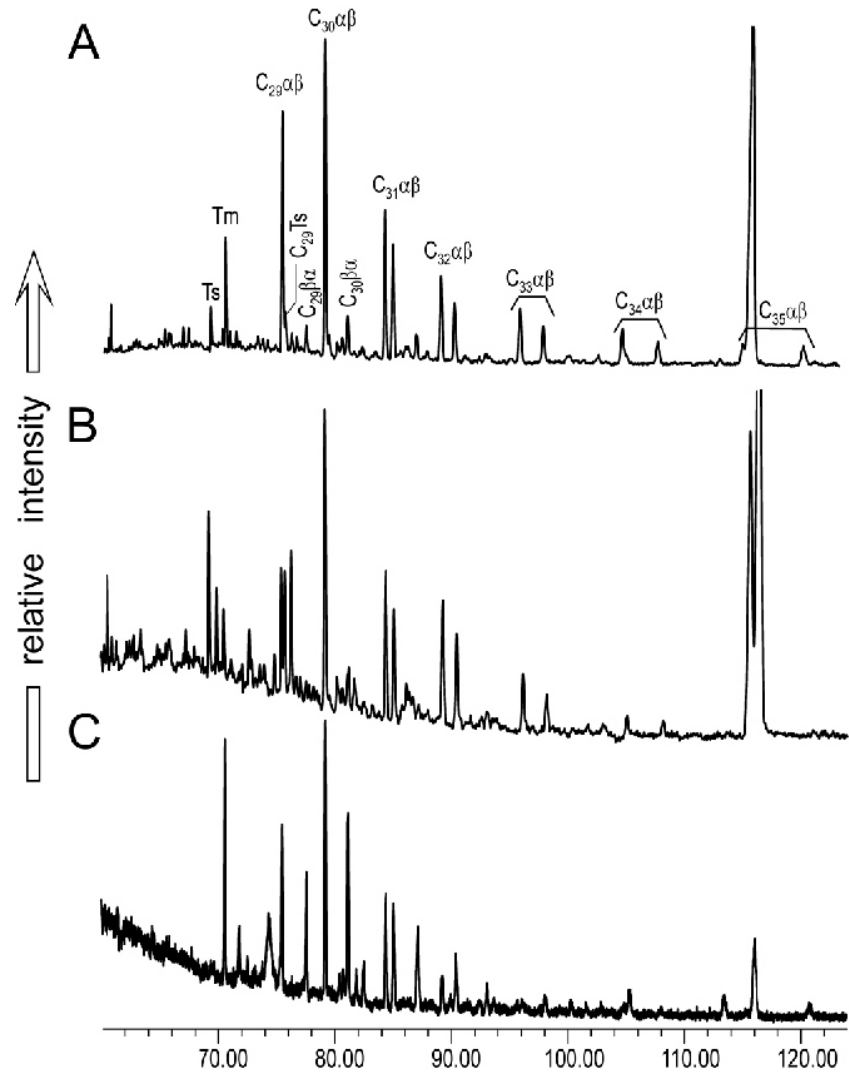

Fig. 12. Distribution types of pentacyclic triterpanes $(m / z=191)$, samples: A - E1 ( $\bullet)$; B - EG4 (O); C - E8 (A)

concentrations of $\mathrm{C}_{35}$ hopanes are indicative of an anoxic- and, possibly, hypersaline sedimentary environment (e.g., samples E7; $\diamond$, E9; $\diamond$, and E10; $\square$; Peters et al., 2005).

2. The shorter type comprises compounds up to bishomohopanes $\left(\mathrm{C}_{32}\right)$ or trishomohopanes $\left(\mathrm{C}_{33}\right)$, commonly with very low compound concentrations. It occurs in samples E2 $(\diamond)$, E3 $(\odot)$, E4 $(\diamond)$, E5 $(\Delta)$, E6 $(\diamond)$, E8 $(\Delta)$, E11 $(\diamond)$, E12 $(\diamond)$, E13 $(\bullet)$, E14 $(\diamond)$, E16 $(\diamond)$ and EG1 $(O)$. This distribution is characteristic for CC and/or TOM predominance in sample what is common in bituminous coals and kerogen Type-III (Peters et al., 2005; Fabiańska et al., 2013).

Comparison of the pentacyclic triterpanes ratios, $\mathrm{C}_{31} \alpha \beta S /(\mathrm{S}+\mathrm{R})$ and $\mathrm{C}_{32} \alpha \beta S /(\mathrm{S}+\mathrm{R})$, reveals discrepancies in their values (Fig. 13). In the process of OM thermal maturation, values of these ratios should remain closely similar as they increase with increasing maturity (Peters et al., 2005). However, where there is input of OM from external sources (CC and TOM) showing different stages of maturation, values of the two ratios can differ not only because of inputs from different sources but also because the relative concentrations of $C_{31} \alpha \beta$ and $C_{32} \alpha \beta$ will differ, depending on the type of $O M$.

Steranes in the range from cholestanes $\left(\mathrm{C}_{27}\right)$ to stigmastanes $\left(\mathrm{C}_{29}\right)$ occur only in some extracts; they are absent in samples EG3 $(\bullet)$, E5 $(\Delta)$, E6 $(\bullet)$, E8 $(\Delta)$, E11 $(\diamond)$, E13 $(\bullet)$ and E14 $(\bullet)$. Generally, samples with high inputs of material from CC and TOM (kerogen Type-III) do not contain steranes. Similarly, in some Upper Silesia bituminous coals, steranes are absent or in concentrations too low for definitive identification (Fabiańska et al., 2013).

In the $\mathrm{Pr} / \mathrm{n}-\mathrm{C}_{17}$ versus $\mathrm{Ph} / \mathrm{n}-\mathrm{C}_{18}$ plot (Fig. 11), samples lacking steranes (predominantly samples with $\mathrm{CC}$ and TOM) plot in the field of coals and kerogen Type-III whereas those with

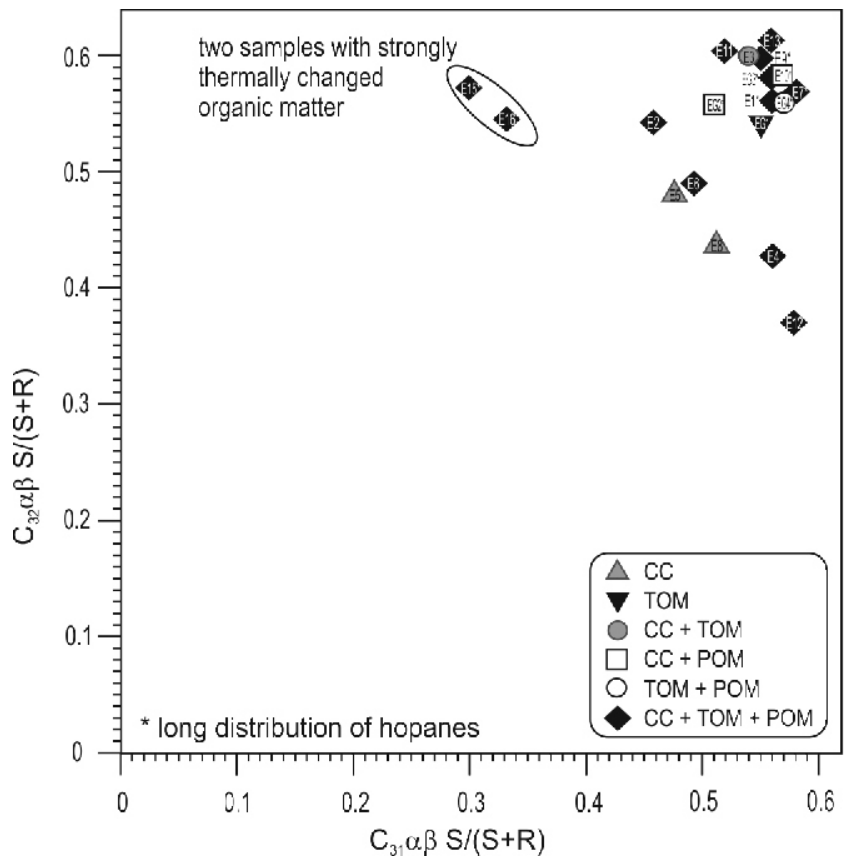

Fig. 13. $C_{31} \alpha \beta S /(S+R)$ versus $C_{32} \alpha \beta S /(S+R)$

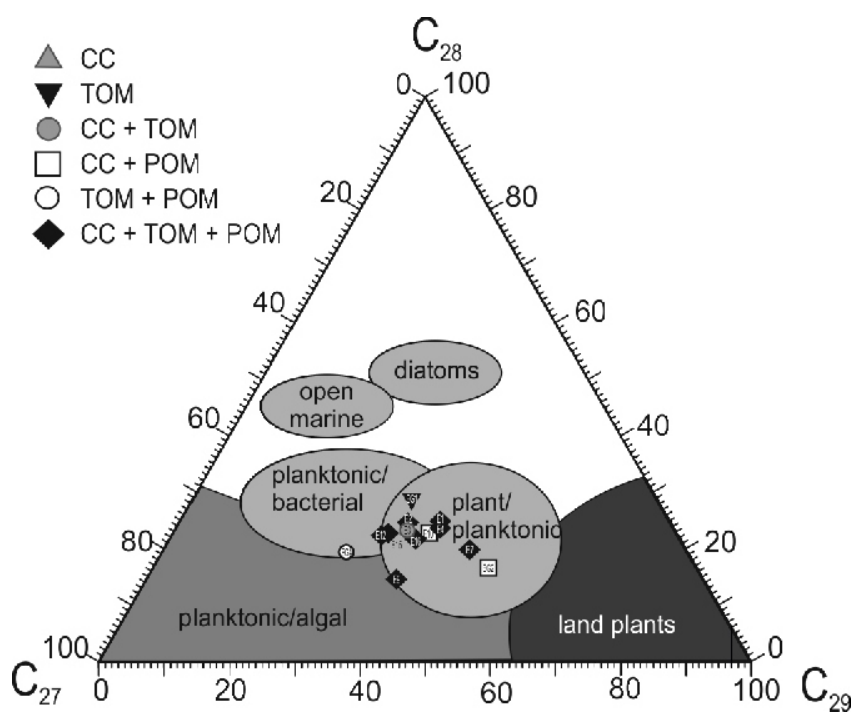

Fig. 14. $\mathrm{C}_{27}-\mathrm{C}_{28}-\mathrm{C}_{29}$ sterane ternary diagram (genetic fields after Huang and Meinschein, 1979)

steranes plot in the kerogen Type-II or kerogen Type-II/III fields (samples containing mixed types of $\mathrm{OM}$ ). Assuming all steranes come from a planktonic source, the $\mathrm{C}_{27}-\mathrm{C}_{28}-\mathrm{C}_{29}$ sterane ternary plot (Fig. 14) suggests that kerogen depositional environment was a continental shelf (Huang and Meinschein, 1979). The $\mathrm{Pr} / \mathrm{Ph}$ versus $\mathrm{C}_{27} / \mathrm{C}_{29}$ sterane plot points to an anoxic sedimentary environment and predominantly algal origin for the $\mathrm{OM}$, except for E1 $(\diamond)$, EG1 $(\bigcirc)$, EG2 $(\square)$ and E7 $(\diamond)$ which plot in the terrestrial field (Fig. 15). It is possible that sterane distributions in the latter samples have been shifted to stigmastanes $\left(\mathrm{C}_{29}\right)$ due to biodegradation which first affects cholestanes as lighter compounds (Palmer, 1993; Wenger et al., 2002; Peters et al., 2005). Samples EG1 (O) and EG2 ( $\square$ ) show signs of this in their $n$-alkane distribution, e.g., in the absence of lighter $n$-al- 


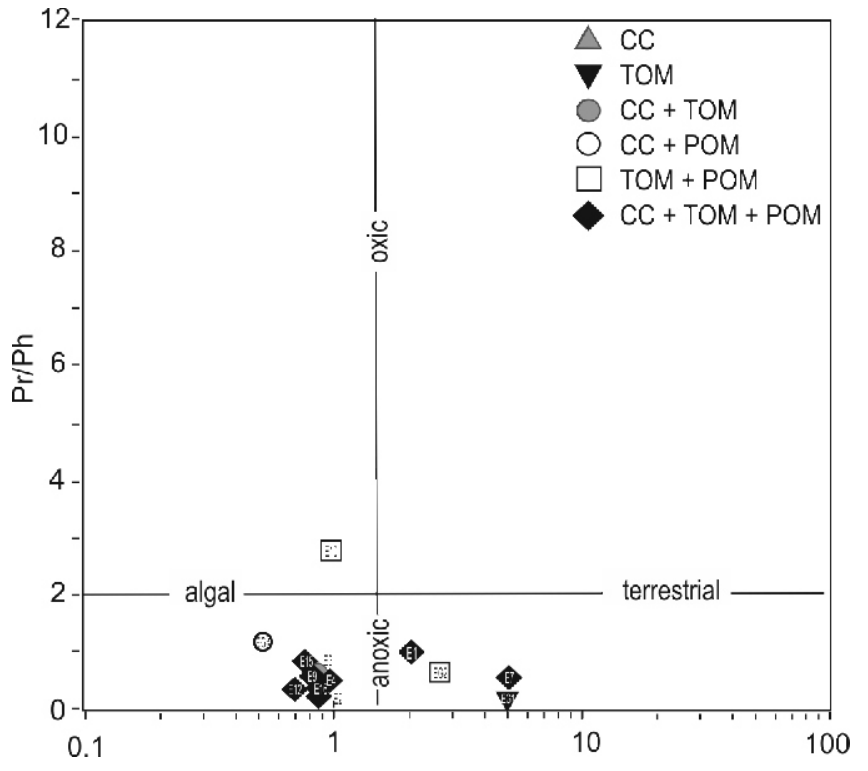

Fig. 15. Pr/Ph ratio versus $\Sigma \mathrm{C}_{29} / \Sigma \mathrm{C}_{27}$ sterane ratio

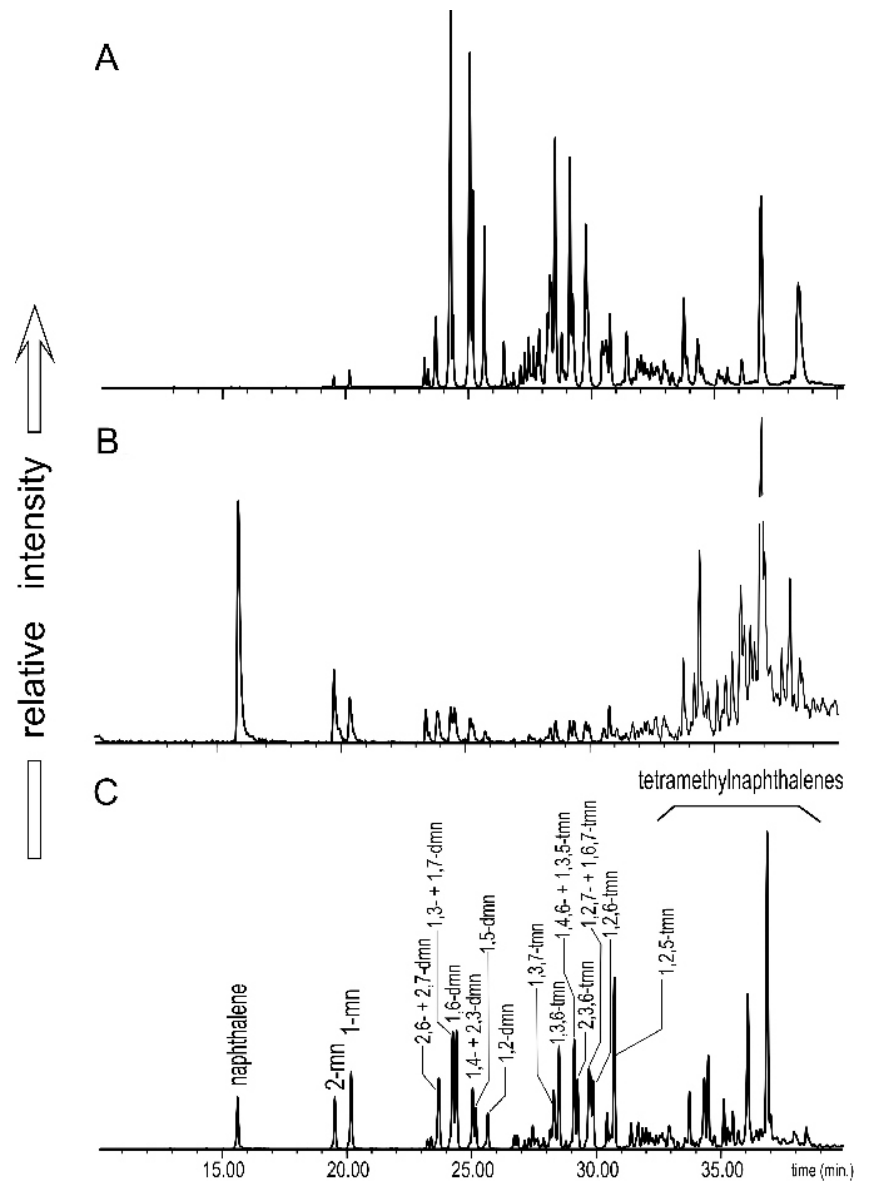

Fig. 16. Distributions of alkylnaphthalenes $(m / z=128+142+156+170+184)$

A - sample E8; B - E1; C - E10

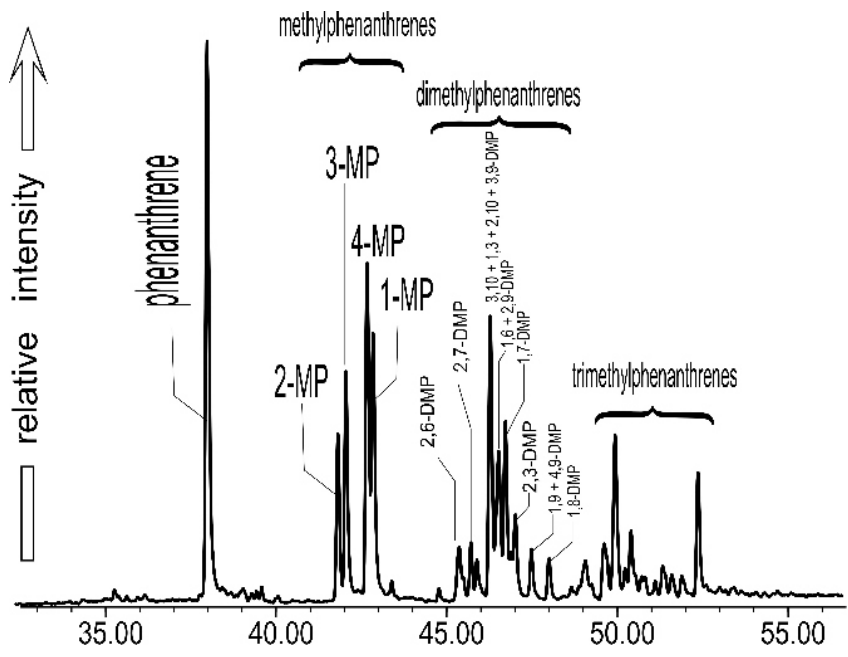

Fig. 17. Distribution of alkylphenanthrenes (sample E7)

kanes and a characteristic "cut out" outline in the $n-\mathrm{C}_{17}-n-\mathrm{C}_{23}$ range, i.e., in the range of $\mathrm{Pr}$ occurrence in the distribution (Fig. 9).

The extracts contain relatively high concentrations of aromatic compounds including unsubstituted polycyclic aromatic hydrocarbons (PAHs) and their alkyl derivatives, together with partially-aromatized compounds and heterocyclic aromatic compounds, mostly of oxygen (Figs. 16 and 17). The alkyl aromatic hydrocarbons were used to calculate several maturity ratios (Appendix 4).

Alkyl naphthalene distributions comprise compounds from methyl $\left(C_{1}\right)$ to $C_{5}$ derivatives, though only $C_{1}$ to $C_{3}$ were in concentrations sufficiently high to enable calculation of parameters of thermal maturity (Appendix 4 and Fig. 16A). Samples with high inputs of $\mathrm{CC}$ commonly have low concentrations of $\mathrm{C}_{1}-\mathrm{C}_{2}$ alkylnaphthalenes, possibly due to water washing/weathering during sedimentary transport. The process most strongly affects naphthalene and methyl- and dimethyl naphthalenes as their solubility in water is greater than that of more substituted $\mathrm{C}_{3}>$ alkylnaphthalenes. Even E8, a CC $\sim 8 \mathrm{~cm}$ long, shows this effect as naphthalene was removed and methylnaphthalenes reduced. The E9 $(\diamond)$, E12 $(\diamond)$, and E13 $(\diamond)$ samples do not contain $\mathrm{C}_{2}-\mathrm{C}_{3}$ alkylnaphthalenes at all nor do E2 $(\bullet)$, E4 $(\bullet)$, and E6 $(\diamond)$ contain dimethylnaphthalenes, whereas E16 $(\bullet)$ contains neither naphthalene nor any alkylnaphthalenes. Such an unusual pattern may reflect the mixing of all three types of OM from either strongly water-washed sources without $\mathrm{C}_{1}-\mathrm{C}_{3}$ alkylnaphthalenes or a source not affected by water washing/weathering in which naphthalene and methylnaphthalene show the highest concentrations (Fig. 16B).

It is also possible that water-washing caused the high variability in MNR (Methylnaphthalene ratio) and DNR (Dimethylnaphthalene ratio) values (Radke et al., 1986; Radke 1987) from 0.60 to 2.23 and from 0.83 to 5.22 , respectively as the solubility of methyl- and dimethylnaphthalenes varies depending on the isomer (ChemIDPlus, https://chem.nlm.nih. gov/chemidplus/). A further significant influencing factor is maturity difference. A similar effect is also apparent in the case of $\mathrm{MPI}-1$ and MPI-3 values (Methylphenanthrene Indices) that range from $0.23-1.82$ and $0.40-1.62$, respectively (Appendix 4). As heavier methylphenanthrenes whose distribution example is shown in Figure 17, are less water soluble than methylnaphthalenes, their distributions are less affected by water washing. Thus, the key influences on MPI-1 and MPI-3 vari- 
ability would seem to be maturity and input from different sources. Alkylphenanthrenes are less affected by water-washing/weathering; only in sample E16 $(\diamond)$ was revealed some removal of these compounds.

\section{DISCUSSION}

\section{ORGANIC-MATTER SOURCES}

Results of the petrographic- and organic geochemical analyses indicate the presence of OM from three different types, i.e., POM, TOM and CC. The various types of OM differ in origin what indicates their morphology, structure, petrographic composition and maturity. Moreover, correlation of the $\mathrm{HI}$ and $T_{\max }$ values (Fig. 7), suggest presence in analysed samples the gas-prone Type-III kerogen derived from vascular plants.

In the $\mathrm{Pr} / \mathrm{n}-\mathrm{C}_{17}$ vs. $\mathrm{Ph} / \mathrm{n}-\mathrm{C}_{18}$ plot (Fig. 11), most of the OM plotting within the transitional depositional environment represents a mixture of Type-II and Type-III kerogens. Samples with the highest TOM input, and E8 comprising a CC, plot within the kerogen Type-III field. Relative contents of $\mathrm{C}_{27}, \mathrm{C}_{28}$, and $\mathrm{C}_{29}$ steranes, determined only for samples without significant $\mathrm{CC}$ input, point to a planktonic-bacterial origin with or without some input of TOM (Fig. 14). Such types of OM are deposited in shelfor deltaic environments proximal to the source of the TOM; destruction of the transported OM did not occur. Correlation of $\mathrm{Pr} / \mathrm{Ph}$ with $\Sigma \mathrm{C}_{29} / \Sigma \mathrm{C}_{27}$ steranes (Fig. 15) points to a predominantly samples containing POM deposited in anoxic settings. However, as most of the samples with OM dominated by CC do not contain steranes, only part of the sample set is shown here, with the exceptions of E10 (comprising 100\% CC; Appendix 1) and EG2 ( $\square$ ) deposited in oxic- and anoxic conditions, respectively. This diversity in OM types thus reflects a variety of $\mathrm{OM}$ sources and sedimentary settings.

Previously studied microfossils in the redeposited humic CC show that the fragments were eroded from the Upper Carboniferous deposits exposured in marginal part of the Carpathian basin (Turnau, 1970; Kotlarczyk, 1979; Florian and Żołdani, 1999; Żołdani, 1999; Wójcik-Tabol et al., 2019). Probably, these coal deposits that were later sediment sources extended far to the south-east of the present Upper Silesian Coal Basin; it is possible that there existed a single coal basin encompassing these and the Upper Silesian and Lublin Coal basins (Turnau, 1970).

TOM is widespread in varying amounts in most Carpathian sediment and it represents OM coeval with the Carpathian hosting sediments. TOM is characterized by a rich in vitrinite and inertinite macerals composition and a lack of any detrital structure indicating carbonization of vascular plants during diagenesis and catagenesis of the Carpathian sediments (Zielińska, 2017). Additionally, the presence of inertodetrinite indicates strongly altered or degraded plant material derived to the sedimentary basin. Sources were mostly land areas located in marginal parts and within the Outer Carpathian basin (e.g., Poprawa et al., 2002; Oszczypko, 2006). Apart from clastic material, these supplied terrestrial OM with different degrees of decomposition and size (Zielińska, 2010; Bąk et al., 2015).

Hydrogen-rich POM in the Carpathians rock with Type II kerogen is mixed with varying amounts of land-plant derived material, and indicates varying thermal maturation. Therefore, POM was divided into two types: POM1 and POM2. POM1 maturity level changes from the immature to the oil window phase and it represents in situ OM in the Carpathian rocks (e.g., Kotarba et al., 2007; Ziemianin, 2017, 2018). Hydrogen-rich POM2 occurs as organic matter with extremely high maturity and/or weathering in the oldest Carpathian strata. We deem this OM has allochthonous origin because of its uniquely high maturity among all OM in the samples studied. There are two hypotheses of such origin.

1. Some of this OM may derived from the Lower Paleozoic strata. Underlying the Carpathian orogen, Ordovician and Silurian formations host potential source rock with Type-II kerogen and alginite predominance (Kotarba and Peryt, 2011; Kotarba et al., 2011; Więcław et al., 2011; Sowiżdżał et al., 2015). The largest predicted hydrocarbons accumulations are near major faults considered migration pathways for oil and gas from the Carpathian basement (Sowiżdżał et al., 2015).

Rock-Eval data indicate strong weathering or bacterial degradation of the OM in E3 $(\bullet)$, E5 $(\Delta)$, E9 $(\bullet)$, E12 $(\bullet)$, E13 $(\diamond)$, E15 $(\diamond)$ and EG4 $(\bigcirc)$ samples evidenced on pyrograms of these samples by a multilobed peak $\mathrm{S}_{2}$ (Fig. 8) during pyrolysis in the temperature range $300-650^{\circ} \mathrm{C}$ (Copard et al., 2006). These samples, containing also redeposited hydrogen-rich organic matter (POM2), represent samples form the strata of Jurassic/Cretaceous age. At the end of the Jurassic, palaeorifts in the southern part of the European shelf were floored by thin continental crust (Birkenmajer, 1988; Sandulescu, 1988; Castelluccio et al., 2015). This rifted European margin was incorporated into the Outer Carpathian basin and rifting process was accompanied by a volcanic activity persisting to the end of the Hauterivian (Lucińska-Anczkiewicz et al., 2002; Grabowski et al., 2004). During the initial stage of its development, the Outer Carpathian sedimentary basin was filled with calcareous flysch followed by siliciclastic sediments and pelagic shales. Early Cretaceous-Cenomanian deposition occurring during relatively low sea levels in the basin was characterized by a lowand decreasing rate of sedimentation (Poprawa et al., 2002). Late Jurassic-Hauterivian deposition was controlled by faulting and syn-rift subsidence, and later by post-rift Barremian-Cenomanian thermal subsidence culminating with Albian-Cenomanian expansion of deep-water facies (Nemčok et al., 2001; Poprawa et al., 2002; Oszczypko, 2004; Andreucci et al., 2013). It is possible that during this time, hydrocarbons from the Carpathian basement migrated along faults into freshly-deposited sediments in the Outer Carpathian basin, the oldest strata in the Silesian nappe profile.

2. Altered POM2 redeposited within the Carpathian strata and it underwent of thermal maturation/weathering, what is indicated by the residue of initial POM in some samples and solid bitumen occurrences. The re-deposition of altered POM2 could be related with the Carpathians post-compression extension phase. In recent years, an alternative model for the Carpathian orogen proposed by Jankowski and Probulski (2011) has envisaged a post-compression extension stage in the evolution of the Outer Carpathians during which reactivation of thrust structures and major block faulting accompanied basement collapse. Reactivated dislocation zones in the Carpathian orogen could well have been migration pathways for hydrothermal fluids and hydrocarbons dispersing widely into sandstone-hosted traps at various stratigraphic levels. Initial planktonic matter was altered by thermal factors and nowadays it represents a residue of hydrocarbons (Waliczek et al., 2019).

\section{THERMAL MATURITY AND HYDROCARBON POTENTIAL}

Vitrinite reflectance values indicate that the degree of coalification depends on OM source. CC show an early-mature $(\mathrm{E} 6 ;-)$ to overmature stage $(\mathrm{E} 11 ; \diamond, \mathrm{E} 13 ; \diamond, \mathrm{EG} 2 ; \square, \mathrm{EG} 3$; ) of hydrocarbon generation corresponding to high-volatile and low-volatile bituminous coal rank. Although many coal seams generate significant amounts of liquid hydrocarbons like 
naturally-occurring oils, poor expulsion efficiency limits their source rock potential. Though assimilation of liquid products by the vitrinitic matrix of most coals severely limits amounts available for migration, significant expulsion may occur from certain liptinite-rich coals or coals in unique depositional settings (Teeman and Hwang, 1991; Hwang et al., 1998). $R_{r}$ values from TOM reveal immature (e.g., E6; $\bullet, E 7 ;$ ) and early-mature stages (e.g., E2; $\bullet, E 11 ; \bullet)$ of hydrocarbon potential indicative of subbituminous $B$ to high-volatile bituminous coal.

$T_{\max }$ values reveal a diversity of maturity dependent on the concentration of OM. Maturity classification based on $T_{\max }$ values (Peters and Moldowan, 1993) shows the OM to indicate immature to mature corresponding with middle stage of oil window. The extremely high $T_{\max }$ values $\left(>490^{\circ} \mathrm{C}\right)$ are result of OM weathering (Copard et al., 2002). The low hydrogen-index values of most samples indicate the presence of gas-prone Type-III kerogen with low hydrocarbon potential.

\section{DEPOSITIONAL ENVIRONMENT}

Geochemical features point to anoxic deltaic or close-shore sedimentary environments in the case of samples with land-plant material (CC and TOM; Figs. 13 and 14). The CC likely originated in coal swamps as did Upper Silesian bituminous coal. The incomplete oxidation of the $\mathrm{CC}$, and the retention of most of their geochemical characteristics, suggest a proximal source. Their transport is seen in the water-washing/weathering of some more soluble compounds, e.g., short-chain $n$-alkanes and methylnaphthalenes.

In the evolution of the Outer Carpathian basin, it seems that the $\mathrm{CC}$ occurrences are mostly related to the post-rift thermal stage and minor uplift of the Outer Carpathians. During the post-rift stage, the basin widened, the rate of subsidence decreased, syn-rift faults became inactive and thermal contraction and sediment loading dominantly controlled subsidence (Hubbard, 1988; Gabrielsen, 2010). During Late Cretaceous, and possibly Paleocene, structural inversion, copious clastic material from cordilleras; deep-sea sediments were deposited and erosion of the source areas exposed coal seams at coastal margins.

\section{CONCLUSIONS}

The Carpathian rocks contain different organic matter provenances: autochthonous and allochthonous ones. This two provenances indicate three different sources of organic matter, namely: CC, TOM and POM.

Each type of OM indicates various features depending on the analysis adopted. During petrographic analysis, in CC a wide range of macerals has been identified, while in TOM only a few maceral forms occurred. All comprise woody organic matter what was also confirmed by the presence of the gas-prone Type-III kerogen by the Rock-Eval and GC-MS analyses. Moreover, GC-MC analysis determined the rocks containing POM2 with the presence of overmature traces of crude oil deriving from planktonic kerogen Type-I or II which could be an allochthonous source. The presence of POM2 residues in the oldest Carpathian deposits is seems to be related to: (i) altered planktonic matter redeposition within the Carpathian strata along reactivated dislocation zones during a post-compression extension stage in the evolution of the Outer Carpathians or (ii) altered planktonic matter re-eposition from the Lower Paleozoic Carpathian basement during the post-rift Barremian-Cenomanian thermal subsidence.

Despite of aquatic transport of CC primary organic geochemical properties of this redeposited material are well preserved allowing to conclude about its features prior redeposition such as thermal maturity and biogenic origin. This indicates relatively short-distance transport, low oxidation (anoxia) and rapid deposition with subsequent covering by fine-grained sediments which did not allow for organic matter mineralization to occur. An important consideration is the fact that redeposited organic matter occurs at sites so differing in age and lithology. This may testify that redeposition should be considered a significant factor in the Outer Carpathians when interpreting geochemical results. Moreover, redeposition of organic matter released as a result of erosion may play a significant role in the global carbon cycle, what is not taken into account in literature.

The additional problem in results interpretation is the type of organic matter investigated by particular methods in relation to secondary process (biodegradation, weathering) occurring in water transport. GC-MS can identify only compounds soluble in organic solvents (in this case DCM) whereas during Rock-Eval analysis is pyrolysing the whole organic material, macromolecular kerogen and bitumen alike. Oxidation, biodegradation and leaching that occur during the transport of organic matter eroded from older rocks will affect at the first stage mostly bituminous fraction of organic matter since it is more reactive than a macromolecular fraction. These processes will lead to formation of refractory material (kerogen IV), non-soluble in organic solvents, thus registered only under a microscope and by Rock-Eval but not by GC-MS. However, migrating bitumen, as we suspect is present in some samples, is well registered on GC-MS but may be not seen under a microscope. Moreover, extreme oxidation of macromolecular fraction will change its chemical features giving material with higher $T_{\max }$ values than that which was not oxidized (Copard et al., 2002).

Acknowledgements. Our thanks go to Dr hab. G. Nowak, Prof. PGI-NRI (Polish Geological Institute-National Research Institute) and anonymous Reviewer bfor comments. The authors are indebted to Dr. P.S. Kennan, University College Dublin (Ireland) for improving the English text. This work was supported by the Centre for Polar Studies, University of Silesia, Poland - The Leading National Research Centre (KNOW) in Earth Sciences 2014-2018; the Statutory Funds for Young Researchers, University of Silesia, Poland (grant No. 1M-0416-001-1-01).

\section{REFERENCES}

Aller, R.C., Blair, N.E., Xia, Q., Rude, P.D., 1996. Remineralization rates, recycling, and storage of $C_{\text {org }}$ in Amazon Shelf sediments. Continental Shelf Research, 16: 753-786.
Andreucci, B., Castelluccio, A., Jankowski, L., Mazzoli, S., Szaniawski, R., Zattin, M., 2013. Burial and exhumation history of the Polish Outer Carpathians: discriminating the role of 
thrusting and post-thrusting extension. Tectonophysics, 608: 866-883.

Arndt, S., Jørgensen, B., La Rowe, D.E., Middelburg, J., Pancost R.D., Regnier, P., 2013. Quantifying the degradation of organic matter in marine sediments: a review and synthesis. Earth-Science Review, 123: 53-86.

Bąk, K., Wolska, A., Zielińska, M., Bak, M., 2015. Coal-bearing submarine slump sediments from Oligocene-Miocene transition of the Eastern Outer Carpathians (Bieszczady Mountains, SE Poland). Geological Quarterly, 59 (2): 300-315.

Berner, R.A., 1989. Biogeochemical cycles of carbon and sulfur and their effect on atmospheric oxygen over Phanerozoic time. Palaeogeography, Palaeoclimatology, Palaeoecology, 73: 97-122.

Birkenmajer, K., 1986. Stages of structural evolution of the Pieniny Klippen Belt, Carpathians. Studia Geologica Polonica, 88: 7-32.

Birkenmajer, K., 1988. Exotic Andrusov Ridge: its role in plate-tectonic evolution of the West Carpathian Fold belt. Studia Geologica Polonica, 91: 7-37.

Bray, E.E., Evans, E.D., 1963. Distribution of $n$-paraffins as a clue to recognition of source beds. Geochimica et Cosmochimica Acta, 22: 2-15.

Bukowy, S., 1957. Observations of the sedimentation of the Babica Clays (Paleocene) in the Middle Carpathians. Bulletin de L'Academie Polonaise des Sciences, Cl. III, 4: 631-635.

Calvert, S.E., Pedersen, T.F., 1993. Geochemistry of recent oxic and anoxic marine sediments: implications for a geological record. Marine Geology, 113: 67-88.

Casttellucio, A., Andreucci, B., Zattin, M., Ketcham, R.A., Jankowski, L., Mazzoli, S., Szaniawski, R., 2015. Coupling sequential restoration of balanced cross section and low-temperature thermochronometry: the case study of the Western Carpathians. Lithosphere, 7: 367-378.

Copard, Y., Disnar, J.R., Becq-Giraudon, J.F., 2002. Erroneous maturity assessment given by $T_{\max }$ and HI Rock-Eval parameters on highly mature weathered coals. International Journal of Coal Geology, 49: 57-65.

Copard, Y., Di-Giovanni, C., Martaud, T., Albéric, P., Olivier, J.E., 2006. Using Rock-Eval 6 pyrolysis for tracking fossil organic carbon in modern environments: implications for the roles of erosion and weathering. Earth Surface Processes, Landforms, 31: 135-153.

Coric, S., 2015. Hydrocarbon potential and depositional environments of Oligo-Miocene rocks in the Eastern Carpathians (Vrancea Nappe, Romania). Marine and Petroleum Geology, 68A: 269-290.

Curtis, J.B., Kotarba, M.J., Lewan, M.D., Więcław, D., 2004 Oil/source rock correlation in the Polish Flysch Carpathian and Mesozoic basement and organic facies of the Oligocene Menilite Shales: insights from hydrous pyrolysis experiments. Organic Geochemistry, 35: 1573-1596.

Didyk, B.M., Simoneit, B.R.T., Brassell, S.C., Eglington, G., 1978. Organic geochemical indicators of palaeoenvironmental conditions of sedimentation. Nature, 272: 216-222.

Di-Govanni, C., Disnar, J.R., Turpin, S., Bréhéret, J.G., 1999. Contribution of reworked organic matter in soils and present lacustrine sediments (Peyssiers basin, Hautes-Alpes, France): preliminary results. Bulletin de la Société Géologique de France, 170: 121-129.

Espitalié, J., Deroo, G., Marquis, F., 1985. La pyrolyse Rock Eval et ses applications. Revue d'Institut Français du Pétrole, 40: 563-579.

Fabiańska, M.J, Ćmiel, S.R., Misz-Kennan, M., 2013. Biomarkers and aromatic hydrocarbons in bituminous coals of Upper Silesian Coal Basin: example from 405 coal seam of the Zaleskie Beds (Poland). International Journal of Coal Geology, 107: 96-111.

Florian, S., Żołdani, E., 1999. Megaspore and cuticular study of coal Peebles from flysch deposits of the Polish Carpathians. Proc. of the 5th European Paleobotanic and Palynology Confererence. Acta Palaeobotanica Supplementum, 2: 33-39.
Gabrielsen, R.H., 2010. The structure and hydrocarbon traps of sedimentary basins. In: Petroleum Geosciences (ed. K. Bjørlykke): 301-318. Springer, Berlin.

Galloway, W.E., Hobday, D.K., 1983. Terrigenous Clastic Depositional Systems. Applications to Petroleum, Coal and Uranium Exploration. Springer, New York.

Golonka, J., Gahagan, L., Krobicki, M., Marko, F., Oszczypko, N., Ślączka, A., 2006. Plate tectonic evolution and paleogeography of the Circum-Carpathian Region. AAPG Memoir, 84: 11-46.

Górecka-Nowak, A., Nowak, G.J., Wójcik-Tabol, P., Uchman, A., 2019. Wiek okruchów węgla z nowych stanowisk w Karpatach Zewnętrznych na podstawie badań miosporowych (in Polish). Pol. Tow. Geol., Uniw. Wrocł. Zakł. Geol. Stratygraficznej Inst. Nauk Geol. Zakł. Paleozol. Inst. Biol. Środowiskowej. XXIV Konferencja Naukowa Sekcji Paleontologicznej Polskiego Towarzystwa Geologicznego. Od prekambru do holocenu zmiany bioróżnorodności zapisane w skałach. Wrocław, Długopole Górne, 11-14 września 2019 r. Materiały konferencyjne (ISBN 978-83-942304-8-7): 34-35.

Grabowski, J., Krzemiński, L., Nescieruk, P., Paszkowski, M., Szydło, A., Pecskay, Z., Wójtowicz, A., 2004. New data on the age of teschenitic rocks (Outer Carpathians, Silesian Unit) - results of K-Ar dating (in Polish with English summary). Przegląd Geologiczny, 52: 40-46.

Graz, Y., Di-Giovanni, C., Copard, Y., Elie, M., Faure, P., Laggoun Defarge, F., Lévèque, J., Michels, R., Olivier J.E., 2011. Occurrence of fossil organic matter in modern environments: optical, geochemical and isotopic evidence. Applied Geochemistry, 26: 1302-1314.

Hedges, J.I., Keil, R.G., 1995. Sedimentary organic matter preservation: an assessment and speculative synthesis. Marine Chemistry, 49: 81-115.

Hedges, J.I., Cowie. G.L., Richey. J.E., Quay. P.D., Benner. R., Strom. M., Forsberg. B. R., 1994. Origins and processing of organic matter in the Amazon river as indicated by carbohydrates and amino acids. Limnology and Oceanography, 39: 119-149.

Hedges, J.I., Keil, R.G., Benner, R., 1997. What happens to terrestrial organic matter in the oceans? Organic Geochemistry, 27: 195-212.

Hedges, J.I., Hu, F.S., Devol, H.A., Harntnett, H.E., Tsamakis, E., Keil, R.G., 1999. Sedimentary organic matter preservation: a test for selective degradation under oxic conditions. American Journal of Science, 299: 529-555.

Hefter, J., Naafs, B.D., Zhang, S., 2017. Tracing the source of ancient reworked organic matter delivered to the North Atlantic Ocean during Heinrich Event. Geochimica et Cosmochimica Acta, 205: 211-225.

Huang, W.-Y., Meinschein, W.G., 1979. Sterols as ecological indicators. Geochimica et Cosmochimica Acta, 43: 739-745.

Hubbard, R.J., 1988. Age and significance of sequence boundaries on Jurassic and early Cretaceous rifted continental margins. AAPG Memoir, 72: 49-72.

Hunt, J.M., 1996. Petroleum Geochemistry and Geology. 2nd Edition. Freeman and Company, New York.

Hwang, R.J., Teerman, S.C., Carlson, R.M., 1998. Geochemical comparison of reservoir solid bitumens with diverse origins. Organic Geochemistry, 29: 505-517.

International Committee for Coal and Organic Petrology, 1998. New vitrinite classification (ICCP system 1994). Fuel, 77: 349-358.

International Committee for Coal and Organic Petrology, 2001. New inertinite classification (ICCP system 1994). Fuel, 80: $459-471$.

ISO 7404-2 (2009). Methods for the petrographic analysis of coals Part 2: Methods of preparing coal samples.

ISO 7404-5 (2009). Methods for the petrographic analysis of coals Part 5: Method of determining microscopically the reflectance of vitrinite.

Jankowski, L., Probulski, J., 2011. Tectonic and basinal evolution of the Outer Carpathians based on example of geological structure of the Grabownica, Strachocina and Łodyna hydrocarbon deposits. Geologia AGH, 37: 555-583. 
Jiang, Z., Duan, H., Liang, Ch., Wu, J., Zhang, W., Zhang, J. 2017. Classification of hydrocarbon-bearing fine-grained sedimentary rocks. Journal of Earth Sciences, 28: 693-976.

Kametaka, M., Takebe, M., Nagai, H., Zhu, S., Takayanagi, Y. 2005. Sedimentary environments of the Middle Permian phosphorite-chert complex from the northeastern Yangtze platform, China; the Gufeng Formation: a continental shelf radiolarian chert. Sedimentary Geology, 174: 197-222.

Koltun, Y., Kotarba, M.J., Kosakowski, P., Espitalie, J., 1995. Hy drocarbon potential of the Menilite and Spas beds in the Polish and Ukrainian parts of the Flysch Carpathians. Extended Abstracts Book, Conference and Exhibition "Modern Exploration and Improved Oil and Gas Recovery Methods," Kraków, Poland: 147-150.

Kosakowski, P., 2013. 1D modelling of hydrocarbon generation and expulsion from Oligocene Menilite source rocks in the San and Stryi rivers region (Polish and Ukrainian Carpathians). Geological Quarterly, 57 (2): 307-324.

Kosakowski, P., Więcław, D., Kotarba, M.J., 2009. Source rocks characteristic of the selected flysch deposits in the transfrontier area of the Polish Outer Carpathians (in Polish with English summary). Geologia AGH, 35: 155-190.

Kosakowski, P., Więcław, D., Kotarba, M.J., Kowalski A., 2012. Habitat and hydrocarbon potential of the Mesozoic strata in the Kraków-Rzeszów area (SE Poland). Geological Quarterly, 56 (1): 139-152.

Kotarba, M.J., Clayton, J.L., 2003. A stable carbon isotope and biological marker study of Polish bituminous coals and carbonaceous shales. International Journal of Coal Geology, 55: 73-94.

Kotarba, M.J., Koltun, Y.V., 2006. Origin and habitat of hydrocarbons of the Polish and Ukrainian parts of the Carpathian Province. AAPG Memoir, 84: 395-442.

Kotarba, M.J., Peryt, T.M., 2011. Geology and petroleum geochemistry of Miocene strata in the Polish and Ukrainian Carpathian Foredeep and its Palaeozoic and Mesozoic basement. Annales Societatis Geologorum Poloniae, 81: 211-220

Kotarba, M.J., Więcław, D., Koltun, Y.V., Marynowski, L., Kuśmierek, J., Dudok I.V., 2007. Organic geochemical study and genetic correlation of natural gas, oil and menilite source rocks in the area between San and Stryi rivers (Polish and Ukrainian Carpathians). Organic Geochemistry, 38: 1431-1456.

Kotarba, M.J., Więcław, D., Kosakowski, P., Wróbel, M. Matyszkiewicz, J., Buła, Z., Krajewski, M., Koltun, Y.V., Tarkowski, J., 2011. Petroleum systems in the Palaeozoic-Mesozoic basement of the Polish and Ukrainian parts of the Carpathian Foredeep. Annales Societatis Geologorum Poloniae, 81: 487-522.

Kotarba, M.J., Więcław, D., Dziadzio, P., Kowalski, A. Bilkiewicz, E., Kosakowski, P., 2013. Organic geochemical study of source rock and natural gas and their genetic correlation in the central part of the Polish Outer Carpathians. Marine and Petroleum Geology, 45: 106-120.

Kotarba, M.J., Więcław, D., Dziadzio, P., Kowalski, A. Kosakowski, P., Bilkiewicz, E., 2014. Organic geochemica study of source rock and natural gas and their genetic correlation in the eastern part of the Polish Outer Carpathians and $\mathrm{Pa}$ leozoic-Mesozoic basement. Marine and Petroleum Geology, 56: 97-122.

Kotarba, M.J., Więcław, D., Bilkiewicz, E., Dziadzio, P., Kowalski, A., 2017. Organic geochemical study of source rock and natural gas and their genetic correlation in the eastern part of the Polish Outer Carpathians and Paleozoic-Mesozoic basement east of Kraków (southern Poland). Geological Quarterly, 61 (4): 795-824.

Kotlarczyk, J., 1979. Occurrence of coal in the Carpathian flysch some sedimentological observations (in Polish with English summary). Rocznik Polskiego Towarzystwa Geologicznego, 18: 37-150.

Kotlarczyk, J., Śliwowa, M., 1963. A contribution to the knowledge of the productive Carboniferous formations in the eastern part of the Carpathians (in Polish with English summary). Przeglad Geologiczny, 11: 268-272.
Králiková, S., Vojtko, R., Hók, J., Fügenschuh, B., Kovac, M., 2016. Low-temperature constraints on the Alpine thermal evolution of the Western Carpathian basement rock complexes. Journal of Structural Geology, 91, doi: 10.2016/j.jsg.2016.09.006

Książkiewicz, M., 1975. Bathymetry of the Carpathian Flysch Basin. Acta Geologica Polonica, 25: 309-367.

Leśniak, T., Waśkowska-Oliwa, A., 2001. Siliciclastic deposits (Paleogene) of the Sub-Silesian Unit in the Żywiec tectonic window area. Kwartalnik AGH Geologia, 27: 51-70.

Lafargue, E., Marquis, F., Pillot, D., 1998. Rock Eval 6 Applications in Hydrocarbon Exploration, Production and Solid Contamination Studies. Oil \& Gas Science and Technology, 53: 421-437.

Leythauser, D., Schwartzkopf, Th., 1985. The pristane/n-heptadecane ratio as an indicator for recognition of hydrocarbon migration effects. Organic Geochemistry, 10: 191-197.

Littke, R., Lükge, A., Wilkes, H., 1998. Organic matter in Neogene sediments of the southern Canary Channel Canary Islands (Sites 955 and 956). Proceedings of the Ocean Drilling Program, Scientific Results, 157: 361-372.

Lucińska-Anczkiewicz, A., Villa, I.M., Anczkiewicz, R., Ślączka, A., 2002. ${ }^{39} \mathrm{Ar} /{ }^{40} \mathrm{Ar}$ dating of alkaline lamprophyres from Polish Western Carpathians. Geologica Carpathica, 53: 45-52.

Matolin, M., Kašparec, I., Hanak, J., Stranik, Z., Ondra, P., Žáček, M., Chlupacova, M., 2007. Physical and chemical properties of flysch sediments in the Ždánice oil deposit (Outer Western Carpathians, Czech Republic). Geologica Carpathica, 33 19-26.

MSD, 2012. The Wiley Registry of Mass Spectral Data. 10th ed. Wiley, New York.

Nemčok, M., Nemčok, J., Wojtaszek, M., Ludhova, L., Oszczypko, N., Sercombe, W.J., Cieszkowski, M., Paul, Z., Coward, M.P., Ślączka, A., 2001. Reconstruction of Cretaceous rifts incorporated in the Outer West Carpathian wedge by balancing. Marine and Petroleum Geology, 18: 39-64.

Nowak, G.J., 2019. Petrological identification of dispersed organic matter in the Silurian shales of the Bardo Mts. (Sudetes) (in Polish with English summary). Przegląd Geologiczny, 67: 183-185.

Oszczypko, N., 2004. The structural position and tectonosedimentary evolution of the Polish Outer Carpathians. Przeglad Geologiczny, 52: 780-791.

Oszczypko, N., 2006. Late Jurassic-Miocene evolution of the Outer Carpathian fold and thrust belt and its foredeep basin (West Carpathians, Poland). Geological Quarterly, 50 (1): 169-194.

Oszczypko, N., Żytko, K., 1987. Main stages in the evolution of the Polish Carpathians during Late Paleogene and Neogene times. In: Global correlation of tectonic movements (eds. G.Yu. Leonov and V. E. Khain): Chapter 11, 187-198. John Wiley and Sons Ltd, Chichester.

Palmer, S.E., 1993. Effect of biodegradation and water washing on crude oil composition. In: Organic Geochemistry. Principles and Applications (eds. M.H. Engel and S.A. Macko): 511-534. New York, Plenum Press.

Pankost, R.D., Baas, M., van Geel, B., Sinninghe Damsté, J.S. 2002. Biomarkers as proxies for plant inputs to peats: an example from a sub-boreal ombrotrophic bog. Organic Geochemistry, 33: 675-690.

Pawlewicz, M., 2006. Total Petroleum Systems of the North Carpathian Province of Poland, Ukraine, Czech Republic, and Austria. United States Geological Survey Bulletin, 2204-D.

Peters, K.E., Moldowan, J.M., 1993. The Biomarker Guide. Interpreting Molecular Fossils in Petroleum and Ancient Sediments. New Jersey, Prentice Hall Inc.

Peters, K.E., Walters, C.C., Moldowan, J.M., 2005. The Biomarker Guide. Biomarkers and Isotopes in Petroleum Exploration and Earth History. 2nd ed. Cambridge University Press.

Philp, R.P., 1985. Fossil Fuel Biomarkers. Application and Spectra. Elsevier, Amsterdam.

Pickel, W., Kus, J., Flores, D., Kalaitzidis, S., Christanis, K., Cardott, B.J., Misz-Kennan, M., Rodrigues, S., Hentschel, A., Hamor-Vido, M., Crosdale, P., Wagner N., 2017. Classifi- 
cation of liptinite - ICCP System 1994. International Journal of Coal Geology, 169: 40-61.

Plašienka, D., 2002. Origin and growth of the West Carpathian orogenic wedge during the Mesozoic. Geologica Carpathica, 94:127-135.

Plašienka, D., Soták, J., 2015. Evolution of Late Cretaceous-Palaeogene synorogenic basins in the Pieniny Klippen Belt and adjacent zones (Western Carpathians, Slovakia): tectonic controls over a growing orogenic wedge. Annales Societatis Geologorum Poloniae, 85: 43-76.

Poprawa, P., Malata, T., Oszczypko, N., 2002. Tectonic evolution of the Polish part of Outer Carpathians sedimentary basins constraints from subsidence analysis (in Polish with English summary). Przegląd Geologiczny, 50: 1092-1108.

Radke, M., 1987. Organic geochemistry of aromatic hydrocarbons. In: Advances in Petroleum Geochemistry 2 (eds. J. Brooks and D.H. Welte): 141-207. New York, Academic Press.

Radke, M., Welte, D.H., 1983. The methylphenanthrene index (MPI): a maturity parameter based on aromatic hydrocarbons. In: Advances in Organic Geochemistry (ed. M. Bjorøy): 504-512. Chichester.

Radke, M., Welte, D.H., Willsch, H., 1986. Maturity parameters based on aromatic hydrocarbons: influence of the organic matter type. Organic Geochemistry, 10: 51-63.

Radke, M., Vriend, S.P., Ramanampisoa, L.R., 2000 Alkyldibenzofurans in terrestrial rocks: influence of organic facies and maturation. Geochimica et Cosmochimica Acta, 64: 275-286.

Sandulescu, M., 1988. Cenozoic tectonics history of the Carpathians. AAPG Memoir, 45: 17-26.

Seifert, W.K., Moldowan, J.M., 1986. Use of biological markers in petroleum exploration. Methods in Geochemistry and Geophysics, 24: 261-290.

Shanmungam, G., 1985. Significance of coniferous rain forests and related organic matter in generating commercial quantities of oil, Gippsland Basin, Australia. AAPG Bulletin, 69: 1241-1254.

Soták, J., Pereszlenyi, M., Marschalko, R., Milicka, R., Starek, D., 2001. Sedimentology and hydrocarbon habitat of the submarine fan deposits of the Central Carpathian Paleogene Basin (NE Slovakia). Marine and Petroleum Geology, 18: 87-114.

Sowiżdżał, K., Słoczyński, T., Matyasik, I., Stadtmuller, M., 2015. Analysis of the Paleozoic oil system in the marginal zone of flysch Carpathians (in Polish with English summary). Nafta-Gaz, (9): 632-646.

Takebe, M., Kametaka, M., Takayanagi, Y., Mimura, K., Sugitani, K., Yamamoto, K., 2007. Origin and deposition of organic matter in continental chert of the Middle Permian Gufeng Formation in the northeastern Yangtze platform. Sedimentary Geology, 201: 141-148.

Teeman, S.C., Hwang, R.J., 1991. Evaluation of the liquid hydrocarbon potential of coal by artificial maturation techniques. Organic Geochemistry, 17: 749-764.

Tissot, B.P., Welte, D.H., 1984. Petroleum Formation and Occurrence. 2nd ed. Berlin, Springer.

Turnau, E., 1970. Plant microfossils and palaeogeography of the Carboniferous coal deposits in Polish Carpathians (in Polish with English summary). Biuletyn Instytutu Geologicznego, 235: 163-244.

Ulmishek, G.F., Klemme, H.D., 1990. Distributional controls, distribution and effectiveness of world's petroleum source rocks. United States Geological Survey Bulletin, 1931: 28-39.

Uziyuk, B.I., Shaynoga, I.B., 2016. Coal exotic fitomass from Upper Cretaceous deposits of the Stryi Formation of the Ukrainian Carpathians - a source of solid, liquid and gaseous hydrocarbons. Science Journal, 2/1: 23-29.

Wagner, M., 1992. Petrological research of Carpathians coal occurrences as a source for hydrocarbons (in Polish with English summary). Gospodarka Surowcami Mineralnymi, 8: 803-817.

Wagner, M., 1996. Petrologic studies of terrestrial organic matter in Carpathians flysch sediments, southern Poland. International Journal of Coal Geology, 29: 259-272.

Waliczek, M., Machowski, G., Więcław, D., Konon, A., Wandycz, P., 2019. Properties of solid bitumen and other organic matter from Oligocene shales of the Fore-Magura Unit in Polish Outer Carpathians: Microscopic and geochemical approach. International Journal of Coal Geology, 210, doi:10.1016/j. coal.2019.05.013

Wendorff, M., Rospondek, M.J., Kluska, B., Marynowski, M., 2017. Organic matter maturity and hydrocarbon potential of the Lower Oligocene Menilite facies in the Eastern Flysch Carpathians (Tarčau and Vrancea Nappes), Romania. Applied Geochemistry, 78: 295-310.

Wenger, L.M., Davis, C.L., Isaksen, G.H., 2002. Multiple controls on petroleum biodegradation and impact on oil quality. SPE Reservoir Evaluation and Engineering, 5: 375-383.

Więcław, D., Kotarba, M.J., Kowalski, A., Kosakowski, P., 2011 Habitat and hydrocarbon potential of the Palaeozoic source rocks in the Krakow-Rzeszow area (SE Poland). Annales Societatis Geologorum Poloniae, 81: 375-394.

Wójcik-Tabol, P., Górecka-Nowak, A., Nowak, G.J., 2019. Preliminary petrological and palinological characteristics of coal clasts from the Menilite Formation of the Silesian Unit (in Polish with English summary). Przegląd Geologiczny, 67: 200-203.

Zielińska, M., 2010. Petrographic structure of terrestrial organic matter in Poland's Western Flysch Carpathians (in Polish with English summary). Geologia AGH, 36: 567-584.

Zielińska, M., 2017. Organic-matter vitrinite reflectance variability in the Outer Carpathians, Poland: relationship to tectonic evolution. Geological Quarterly, 61 (1): 214-226.

Ziemianin K., 2017. Petrographic-geochemical characterization of the dispersed organic matter in menilite shales from the Silesian Unit in the Carpathian Mountains of SE Poland. Nafta-Gaz, (11): 835-842.

Ziemianin K., 2018. Characteristics of dispersed organic matter in Menilite Beds from the Skole Unit. Nafta-Gaz, (9): 636-646.

Żołdani, E., 1999. Palynological studies of the Carboniferous coal pebbles from the region of the Carpathians (in Polish with English summary). 22nd Symposium Geology of Coal-bearing Strata of Poland, Proceedings, Cracow, April 21-22, 1999: $135-138$. 